\title{
Characterization of Microschist Rocks under High Temperature at Najran Area of Saudi Arabia
}

\author{
Haitham M. Ahmed *(D), Hussin A. M. Ahmed (D) and Sefiu O. Adewuyi (D) \\ Mining Engineering Department, King Abdulaziz University, Jeddah 21589, Saudi Arabia; \\ haahmed@kau.edu.sa (H.A.M.A.); sadewuyi@stu.kau.edu.sa (S.O.A.) \\ * Correspondence: hmahmed@kau.edu.sa
}

Citation: Ahmed, H.M.; Ahmed,

H.A.M.; Adewuyi, S.O

Characterization of Microschist Rocks under High Temperature at Najran Area of Saudi Arabia. Energies 2021, 14, 7612. https://doi.org/10.3390/ en14227612

Academic Editor:

Nikolaos Koukouzas

Received: 19 October 2021

Accepted: 10 November 2021

Published: 15 November 2021

Publisher's Note: MDPI stays neutral with regard to jurisdictional claims in published maps and institutional affiliations.

Copyright: (C) 2021 by the authors Licensee MDPI, Basel, Switzerland. This article is an open access article distributed under the terms and conditions of the Creative Commons Attribution (CC BY) license (https:/ creativecommons.org/licenses/by/ $4.0 /$ )

\begin{abstract}
Rocks' physical, mechanical, and mineralogical properties are essential in the design process of underground applications. To understand changes in these rocks' properties at high temperatures, numerous studies have been conducted on several rock types, with little being known about microschist rock. This paper presents experimental study on the physical (e.g., density and P-wave velocity), mechanical (uniaxial compressive strength (UCS)), and microstructural behavior of microschist rock at room temperature $\left(22^{\circ} \mathrm{C}\right)$ and at high temperatures, i.e., 400,600 , and $800{ }^{\circ} \mathrm{C}$. The results indicated that as the temperature increases, the microschist's color changed, and dry density decreased by $0.97 \%$ at $800{ }^{\circ} \mathrm{C}$. Additionally, the average P-wave velocity of microschist decreased by $4.14,7.07$, and $34.23 \%$, at 400,600 , and $800{ }^{\circ} \mathrm{C}$, respectively. Similarly, at these temperatures, the UCS of the microschist decreased by $34.4,56.9$, and $80.1 \%$, respectively. Further findings from microscopic studies reveal that the observed changes in physical and mechanical properties were due to the structural deformation of the microschist at high temperatures.
\end{abstract}

Keywords: heating; microschist; P-wave; uniaxial compressive strength; microstructure

\section{Introduction}

The mechanical and physical properties of rocks are the key parameters in the applications and engineering designs. Unfortunately, some of these properties are subjected to major changes due to heating. Therefore, the investigation of rock's behavior at high temperature is a hot topic in the literature. Numerous studies have been devoted to characterizing rocks at high temperatures in different areas of specializations, including geothermal energy exploitation [1], underground coal gasification [2,3], nuclear energy disposal [4,5], hydrothermal systems, archaeology [6,7], the construction of roads and buildings [8,9], rock drilling and blasting, underground tunnels [10], thermal energy storage (TES) [11-14], and deep mining engineering [15]. The changes in rock properties due to heating depend on different parameters including rock's thermal properties, maximum applied temperature, exposure time, heating/cooling rates, in addition to rock mineral composition and its texture $[9,16,17]$. If rock's parameters were altered by increasing temperature, the mechanical and physical properties of rock such as strength (uniaxial compressive strength (UCS)), P-wave velocity, density, mineral phases, and color may be affected.

As per the effect of high temperature on the strength of rocks, numerous studies have been carried out on several rock types such as sandstones [2,17-22], granite [1,15,16,19,23,24], limestone [17,25-27], marble [17,28], mudstone [2,3], calcarenite [27], diabase [29], and basalt [14]. The findings show that different possible effects can take place on the strength of rock after heating to high temperatures. For instance, the rock strength may not change with temperature, it may continuously increase, continuously decrease, or return a mixed behavior, i.e., increase/decrease or vice versa. These effects of high temperatures on rocks' strength were attributed in the literature mainly to variation in the thermal expansion of the constituent minerals, differences in thermal spallation within the rock matrix and 
crack generation [30]. Findings indicated that the compressive strength of limestone does not change until $700{ }^{\circ} \mathrm{C}$, where a sharp decrease in strength was observed [17]. For granite, marble, and mudstone, it was found that their strength decreases with temperature, especially above $400{ }^{\circ} \mathrm{C}[17-19,23,25]$. In the same manner, calcarenite rocks showed a decrease of up to $35 \%$ in its uniaxial compressive strength (UCS) after heating to $600{ }^{\circ} \mathrm{C}$ [27]. Conversely, results indicated that the strength of sandstone increases gradually up to $600^{\circ} \mathrm{C}$, then, the strength dropped at higher temperatures [17]. In another study on sandstone, its UCS decreased by about $42.9 \%$ between 100 and $400{ }^{\circ} \mathrm{C}$, increased between 400 and $900{ }^{\circ} \mathrm{C}$, and drastically decreased at $1200^{\circ} \mathrm{C}$ [2].

The effect of high temperature on the P-wave velocity of sandstone [18,19], marble [28], and granite [31,32] has also been studied. It was discovered that the P-wave velocities of these rocks decreased as the temperature increases, but remain nearly the same at a specific temperature for sandstone and marble $[18,19]$. At 500 and $600{ }^{\circ} \mathrm{C}$, the P-wave velocities of granite decreased by 32 and $63 \%$, respectively, suggesting that the path traveled by the wave was irreversibly altered after the heating experiment $[32,33]$. However, P-wave velocity cannot be used alone to indicate strength reduction after heating operation, because rock strength can increase or decrease after heating to a high temperature [17].

Changes in the densities and colors of rocks have been studied [34-37]. Findings showed that the color of rock changes as the temperature changes, especially above $400{ }^{\circ} \mathrm{C}$ [34-37]. Results also indicated that the densities of rock decreased due to increased volume and loss in mass due to dehydration or mineral decomposition after heating experiment [33]. To a certain extent, this is caused by changes in the microstructure of rock [33]. Apart from density and color change, heating rock to a high temperature also causes either crystal peaks in the X-ray diffraction (XRD) patterns relative to the specific crystals disappearing, or the formation of new peaks in the XRD patterns occur due to phase shift; indicating formation of new mineral phase due to mineral decomposition at a specific range of temperatures [21].

It can be inferred from hitherto discussed studies that high temperature has a great impact on the physical, mechanical, and mineralogical properties of rocks. Additionally, the dominant rocks studied in the literature are granite, sandstone, and limestone. To the best of our knowledge, information on the effect of high temperatures on microschist's mechanical, physical, and microstructural properties is scarce in the literature and thus need to be investigated. This becomes a must when taking into consideration the dominant spread of microschist in many Saudi mines, especially in the southwestern part of the kingdom (Najran area). Therefore, this paper presents the characterization of microschist selected from the Najran area, Saudi Arabia. The study will focus on the effect of high temperature on microschist's mechanical, physical, and microstructural properties. The results from this study will contribute to different industrial applications where microschist can be used as a input raw material (e.g., filler, building and construction industries) [9], or as a surrounding environment (mining, tunnel, and geothermal) [1]. In addition, the paper also provides a statistical analysis perspective of the obtained data which may be adopted in sample selection for planning purposes in structural engineering system designs, for temperature-dependent applications.

\section{Materials and Methods}

\subsection{Sample Collection and Preparation}

The diamond drill-core rock samples used in this study were supplied by Al Masane AlKobra mining company (AMAK, Najran, Southwest, Saudi Arabia; Figure 1). The core was drilled up to $31 \mathrm{~m}$ beneath the Earth's surface, and samples were arranged in different containers according to depth. However, intact core rock samples at the deeper part, between 21 and $31 \mathrm{~m}$ (Figure 2a), were used for this study. Forty-five representative core samples (diameter $-63.55 \mathrm{~mm}$ ) suitable for the point load strength index (PLSI) test were prepared according to the ASTM standards [38,39]. Rock samples with a length to diameter ratio between 1/3 and 1 were cut using a rock cutter machine (PT100, GCTS 
Testing Systems, 6103 South Maple Avenue, Tempe, AZ 85283, USA), and surface polishing was performed by a rock surface grinder machine (KGS618, Tustin, CA 92680, USA). All prepared samples were dried at $105^{\circ} \mathrm{C}$ for $24 \mathrm{~h}$ (Binder dryer, Binder Inc., Bohemia, NY 11716 , USA). Sampling of the drill-core is a major bottleneck due to the nonhomogeneous nature of rocks [40]. However, its impact was mitigated by arranging the prepared samples according to the depth. The samples were then divided into four groups by ensuring that each group has equal specimens from the same depth and all considered depths were duly represented, for quality assurance and control purposes. In addition, minerallogy was also considered during sampling, as some specimens had a feasible silica content. The specimens were then labeled using different numerations; for instance, S-0-1 represents sample 1 at $22{ }^{\circ} \mathrm{C}$ (zero stands for room temperature), S-0-2 represents sample 2 at $22{ }^{\circ} \mathrm{C}$, and S-0-10 stands for sample 10 at $22^{\circ} \mathrm{C}$. For another set of samples, S-1-1, S-2-1, and S-3-1 represent sample 1 at 400,600 , and $800{ }^{\circ} \mathrm{C}$, respectively. Forty of the prepared core samples are presented in Figure $2 b$.

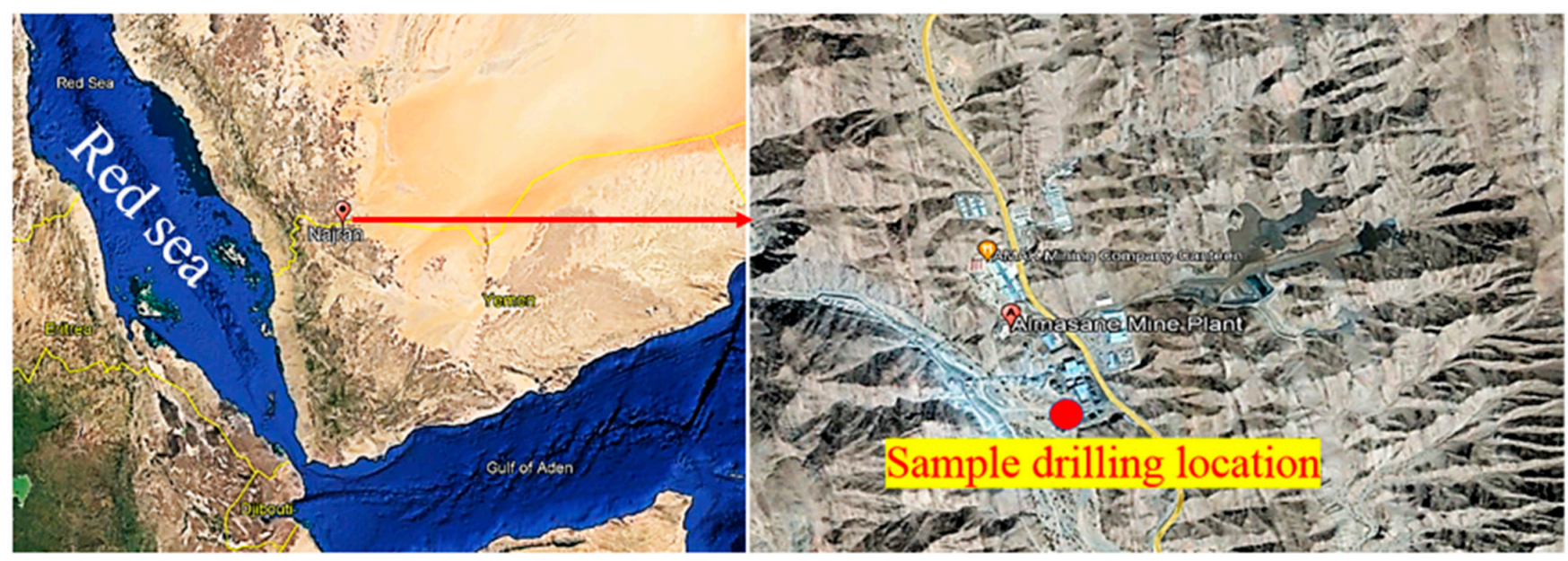

Figure 1. Core drill location, Najran, Saudi Arabia (images were captured using open source Google Earth Pro; 1600 Amphitheatre Parkway, Mountain View, CA 94043, USA).

\subsection{Sample Characterizations}

Different analytical techniques were used for characterizations, including SEM-EDX, petrographic (thin section), XRD, and SEM analyses. Representative samples were prepared before and after heating. For SEM-EDX, XRD, and SEM analyses, representative as-received unheated and heated powder samples were prepared using the same procedure, to establish the elemental composition, mineralogy, and morphology. Specimens were obtained from the target test samples $\left(22,600\right.$, and $800^{\circ} \mathrm{C}$ ). Obtained rock fragment specimens (at different target temperatures) were separately crushed by a hand-held hammer and later ground using a planetary mill until $100 \%$ of the particles passed a $100 \mu \mathrm{m}$ diameter sieve.

For each SEM-EDX characterization, a representative noncoated powder sample was fixed on the stub using carbon tape and then put into an SEM (JSM-7600F, Tokyo, Japan) sample chamber where the representative specimen area was selected after the electron beam illuminated the sample. The average constituent elements were then recorded by the EDX spectrometer (EDX, Oxford instruments, Abingdon, Oxfordshire, UK) using five iterated values [41]. The SEM image of each sample was taken at different magnifications to observe the specimen morphology. The XRD spectra of the representative powder specimens were obtained in a continuous mode at a scattering angle $2 \theta$ between $5^{\circ}$ and $90^{\circ}$ with a increment of $0.05^{\circ}$ using an X-ray diffractometer (Regaku, Ultima 1V, Japan; $40 \mathrm{~mA}$, $40 \mathrm{kV}, \mathrm{Cu} \mathrm{k} \alpha$ radiation) [41,42]. The peak intensities of the XRD spectra were matched with the standard spectra using "PowderX" software (National Lab. for Superconductivity (NLSC), Institute of Physics, Chinese Academy of Sciences, Beijing 100190, China) [43] and 
"Match!" Software (Version 3.12 Build 210 for Windows 64-bit, Crystal Impact GbR, Bonn, Germany) for quantitative and qualitative analysis.

(a)

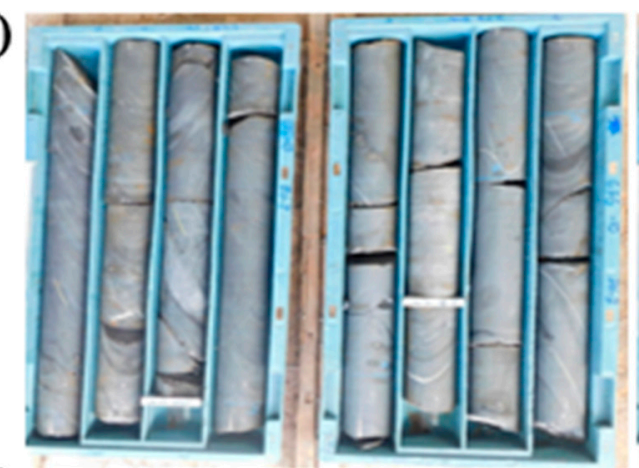

(b)
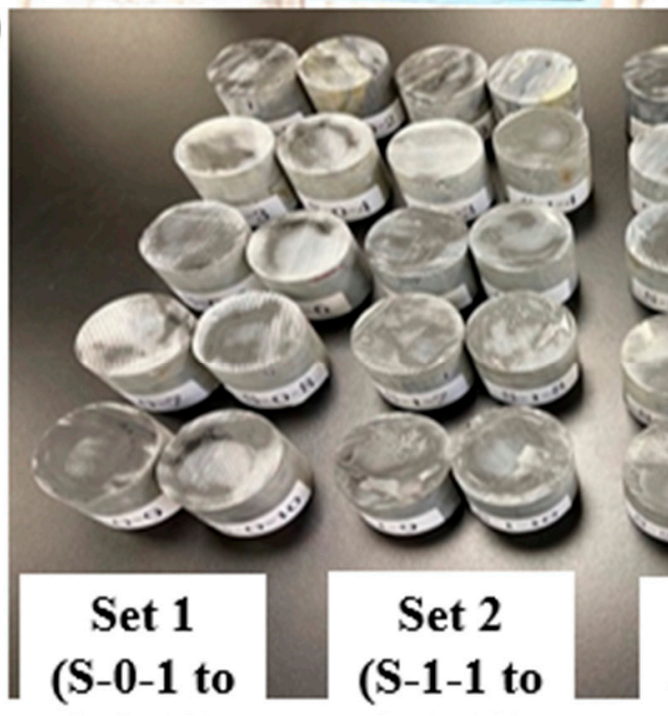

S-0-10)
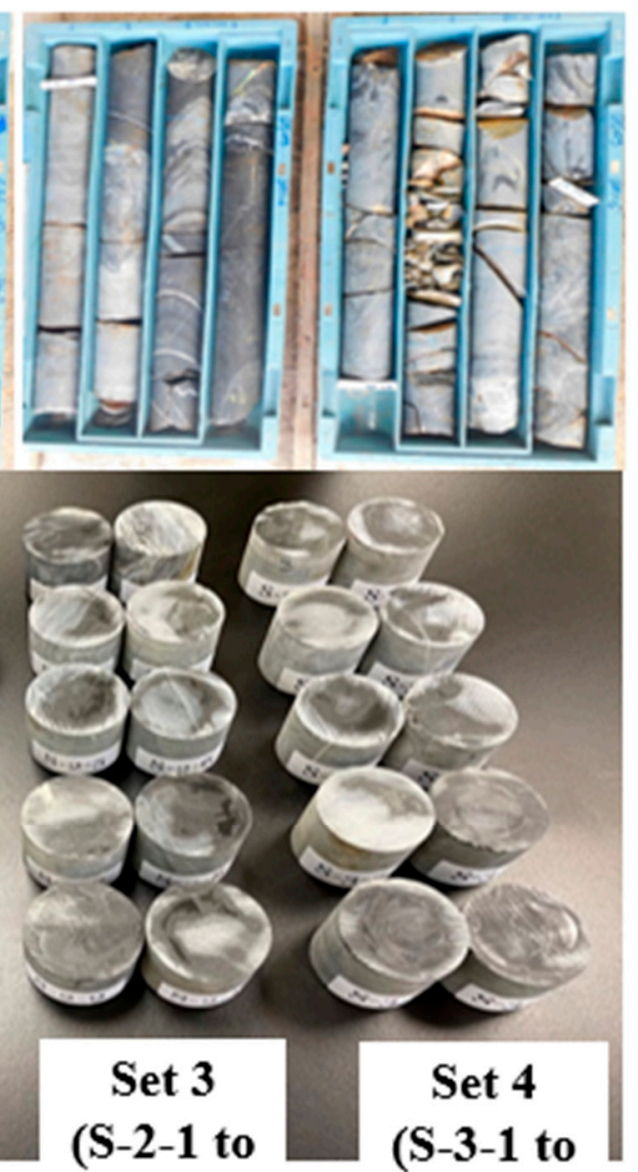

S-2-10)

Figure 2. (a) Core sample trays; (b) prepared representative samples (S-0-1 to S-0-10; samples for room temperature tests, S-1-1 to S-1-10; samples for $400{ }^{\circ} \mathrm{C}$ tests, S-2-1 to S-2-10; samples for $600{ }^{\circ} \mathrm{C}$ tests, S-3-1 to S-3-10; sample for $800{ }^{\circ} \mathrm{C}$ tests.

For the petrographic study, representative core samples were physically examined under Leica S9i stereomicroscope (USA), and standard petrographic thin sections were prepared (Figure 3) from representative areas for the samples at $22^{\circ} \mathrm{C}$ (room temperature; S1), $600{ }^{\circ} \mathrm{C}$ (S2), and $800{ }^{\circ} \mathrm{C}(\mathrm{S} 3)$, to establish host rock lithology, mineral composition, texture, deformation, and alteration. Each representative standard thin sample section was observed microscopically under transmitted light using a research polarizing microscope (Olympus BX53M, Japan), and representative photomicrographs were taken by the digital camera Olympus SC180 attached to the microscope.

\subsection{Density and P-Wave Velocity}

Density is one of the physical parameters of rocks used in numerical modeling analysis and design. To determine the dry density of the studied microschist, the mass and volume of all sets of samples (set 1 to set 4 ) were determined at room temperature $\left(22^{\circ} \mathrm{C}\right)$. The dry density for each sample was calculated by dividing the dry mass of the sample with the dry volume of the sample, as earlier discribed in the literature [44], and the average dry density of the samples was determined. The procedure was repeated for set 2 , set 3 , and set 4 after heating to 400,600 , and $800^{\circ} \mathrm{C}$. 
(a)
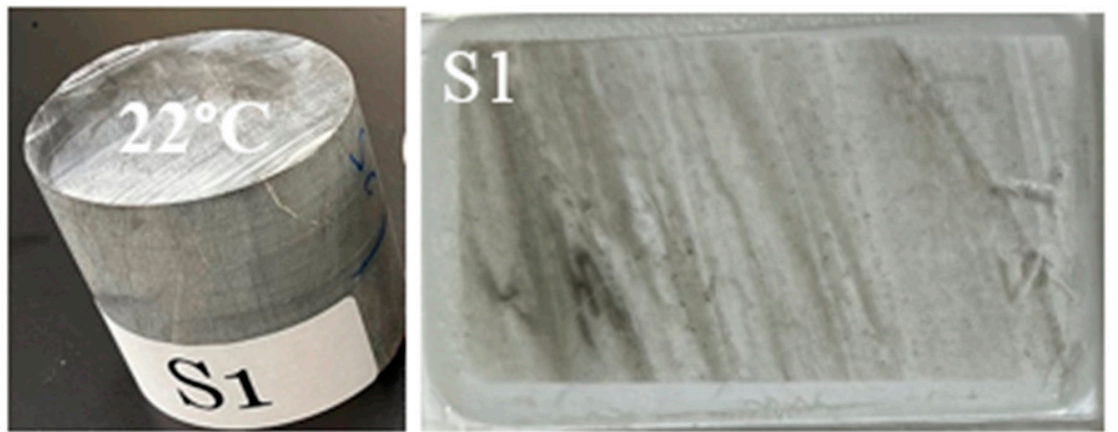

(b)

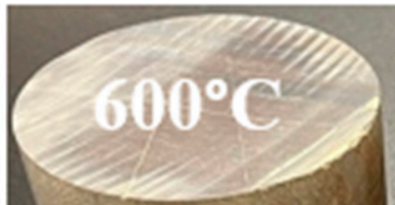

(c)
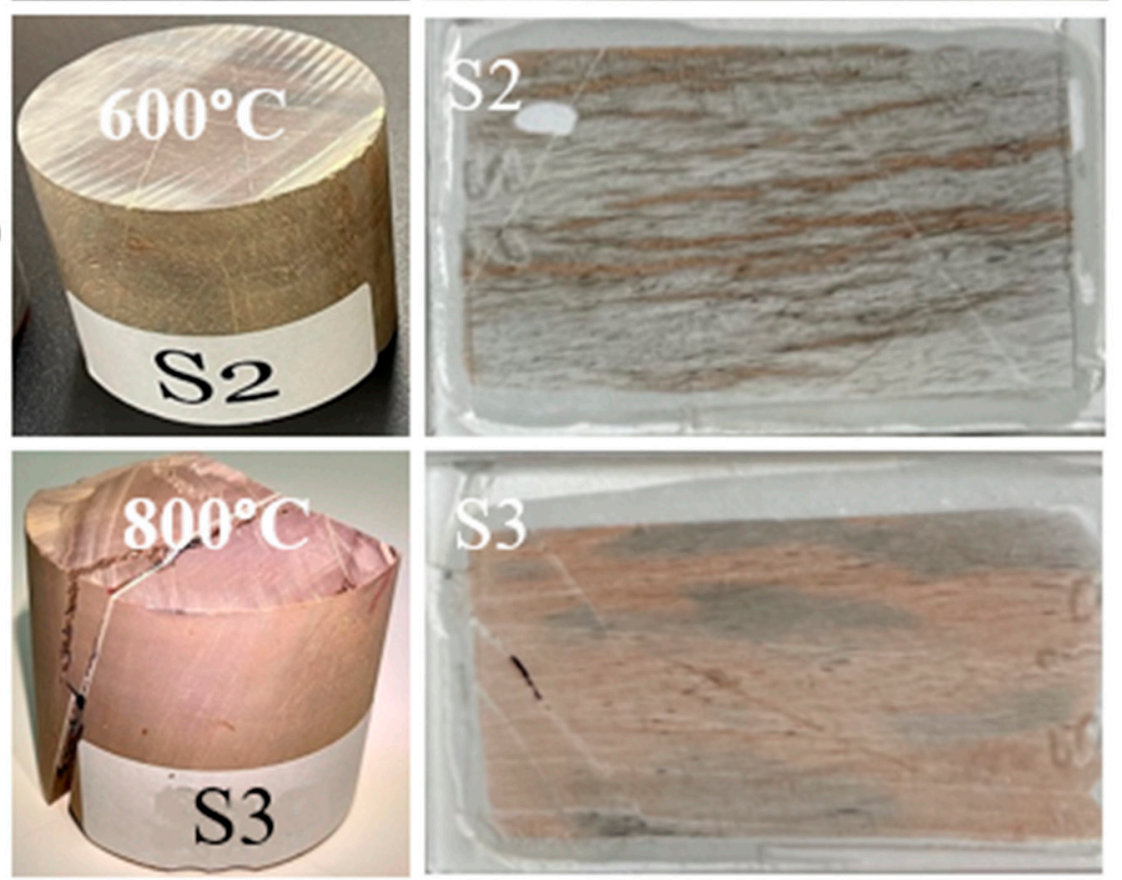

Figure 3. To the left; hand-held specimens, to the right; thin sections from the representative area of hand-held specimens (a) S1 $\left(22^{\circ} \mathrm{C}\right)$, (b) S2 $\left(600^{\circ} \mathrm{C}\right)$, (c) S3 $\left(800^{\circ} \mathrm{C}\right)$.

The P-wave velocity is one of the physical properties usually measured to assess the effect of temperature on rock's internal structure. To measure the P-wave velocity, lubricant was applied on the opposite surfaces of the sample as a coupling medium between transducers (transmission and receiving) and the sample's surfaces, to ensure efficient energy transfer [45-47]. The P-wave velocities of the samples were measured before and after heating using an ultrasonic velocity measurement device (Pundit PL 200, Switzerland). Measurement was repeated three times to ensure accurate values of the $\mathrm{P}$-wave velocities of the samples were taken. Since ten samples were considered for each specific test condition $\left(22,400,600\right.$, and $\left.800{ }^{\circ} \mathrm{C}\right)$, the average $\mathrm{P}$-wave velocity for each test category (set 1: $22{ }^{\circ} \mathrm{C}$, set 2 : $400{ }^{\circ} \mathrm{C}$, set 3: $600{ }^{\circ} \mathrm{C}$, and set $4: 800{ }^{\circ} \mathrm{C}$ ) was determined.

\subsection{Heating Experiments}

The previously prepared microschist rock samples were heated using a laboratory furnace (CHM-60H, maximum temperature-1600 ${ }^{\circ} \mathrm{C}$, Jim-bomb Enterprise Co., Ltd., Taiwan). This furnace was used to heat rock samples of set 2 , set 3 , and set 4 to the target temperatures: 400,600 , and $800{ }^{\circ} \mathrm{C}$, respectively. The minimum target temperature of $400{ }^{\circ} \mathrm{C}$ was considered, since findings from previous studies showed that below this temperature, little or no significant change in mechanical and physical properties may be observed, especially for rocks with abundant rock-forming minerals (such as quartz and feldspar), as is the case in this study $[18,19,23,25]$. In addition, the results of the electrical conductivity study of a rock sample (consisting of quartz, albite, muscovite, 
and clinochlore) in the study area (Najran, Saudi Arabia) show that the rock exhibited thermal stability up to around $370{ }^{\circ} \mathrm{C}$ [48]. Furthermore, to avoid splitting samples into pieces (Figure 4, right-hand side; samples heated to $900^{\circ} \mathrm{C}$ ), $800^{\circ} \mathrm{C}$ was considered as the final target test temperature to make samples suitable for the point load strength index and P-wave velocity experiments. In this study, ten representative samples were heated at once from room temperature to the target temperature of $400{ }^{\circ} \mathrm{C}$ at a heating rate of $5{ }^{\circ} \mathrm{C} / \mathrm{min}$ [44]. The samples were kept at target temperature for an hour and then cooled to room temperature (inside the furnace) at an average cooling rate of $1.5 / \mathrm{min}$ to avoid thermal shock, as is the case for rapid cooling [45,49]. This procedure was repeated using another set of ten representative samples at maximum target temperatures of 600 and $800{ }^{\circ} \mathrm{C}$, by keeping the heating rate and cooling rate conditions the same as those used for samples at $400^{\circ} \mathrm{C}$, for quality assurance and quality control purposes.
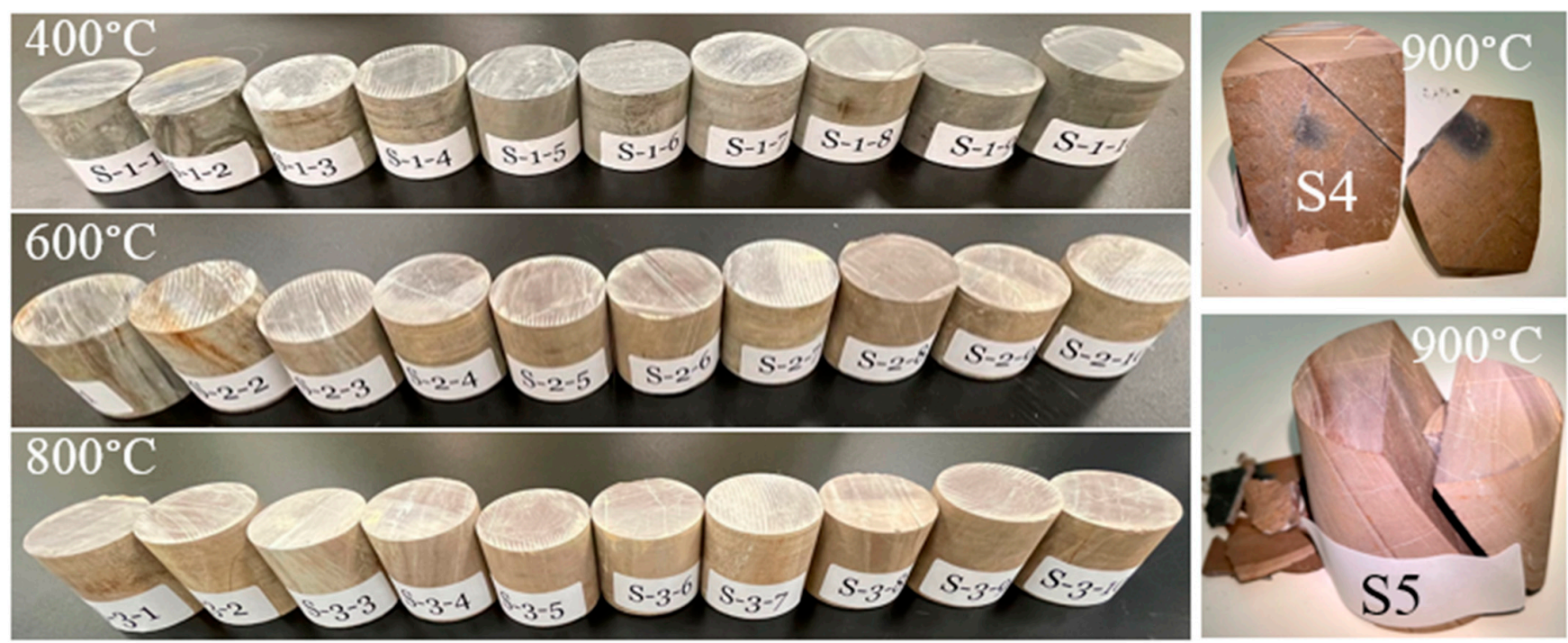

Figure 4. Samples after heating experiments (from room temperature to $400,600,800$ and $900{ }^{\circ} \mathrm{C}$ ).

\subsection{Estimation of UCS Using the Point Load Test}

To estimate the effect of high temperature on rock strength, the point load test was conducted as a cost-effective and easier method of estimating the UCS of rocks using the ASTM standard [39]. Forty samples were tested for all target temperatures, with 10 representative core samples for either $22,400,600$, and $800{ }^{\circ} \mathrm{C}$, for quality assurance and quality control purposes, according to the ASTM procedure [39]. The length of each core sample, equivalent to the platen separation distance $(D)$, and the width $(W)$ were measured and recorded (Figure 5a; PLT 110, GCTS, 6103 South Maple Avenue, Tempe, AZ 85283, USA). The platens were closed to make firm axial contact with the sample, and the load was gradually increased until failure after between 10 and $60 \mathrm{~s}$, according to the ASTM standard (Figure 5) [39]. The failure load $(P)$ was measured and recorded [39]. The uncorrected PLSI $\left(I_{S}\right)$ and the size-corrected PLSI $\left(I_{s(50)}\right)$ were calculated for each sample using Equation (1) and Equation (2), respectively. Since ten samples were tested at each target temperature $\left(22,400,600\right.$, and $\left.800^{\circ} \mathrm{C}\right)$, the average $I_{s(50)}$ was calculated and recorded at each target temperature [39]. The site correlation factor of the studied sample is not available; therefore, a generalized conversion factor value of 23 was used to convert the corrected point load strength index to UCS according to the ASTM standard [39].

$$
\begin{gathered}
I_{S}=\frac{P \times \pi \times 1000}{4 W D} \\
I_{s(50)}=I_{S} \times\left(\frac{D}{50}\right)^{0.45}
\end{gathered}
$$




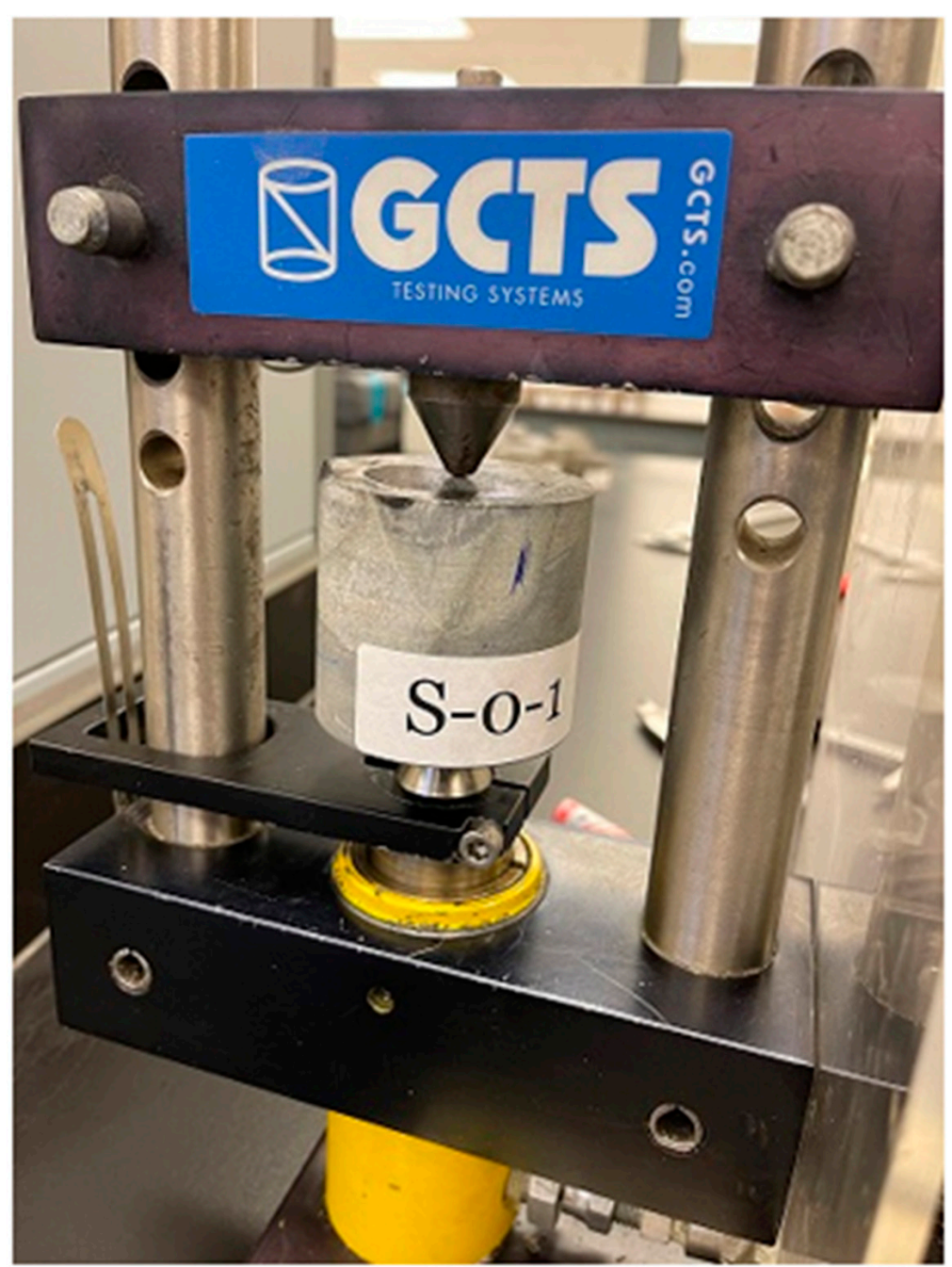

(a)

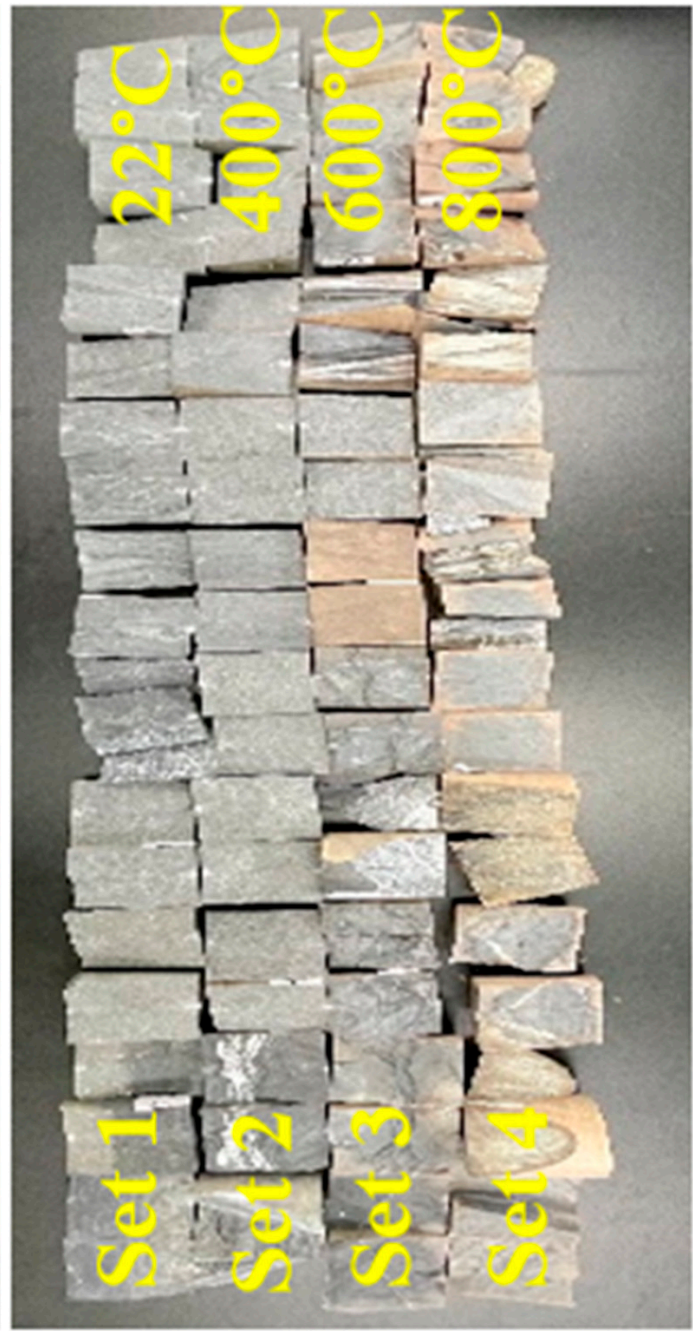

(b)

Figure 5. (a) Representative core samples during the point load test; (b) samples after the point load test.

\section{Results and Discussions}

\subsection{Color}

Color is one of the observable physical properties which can be used to identify and categorize rocks. The physical appearance of rock can sometimes be changed due to increasing temperature [34]. The reference microschist (unheated) rock sample $\left(22{ }^{\circ} \mathrm{C}\right)$ and the heated samples $\left(400,600\right.$, and $\left.800{ }^{\circ} \mathrm{C}\right)$ are compared as shown in Figure 6 . It can be observed that as the temperature increases, the color of the samples changes from black-gray for unheated to red-brown after heating. This can be clearly distinguished, especially at 600 and $800{ }^{\circ} \mathrm{C}$. Color changes of rocks after heating experiments have been reported in literature [34-36]. This phenomenon may be attributed to the presence of Fe in the sample, as observed in previous studies [34,36]. Apart from this, microcracks, the displacement of impurities, and microvoids that may occur during the heating process have also been reported to cause changes in the color of rocks [47]. Based on color observation of the studied microschist samples after heating, SEM-EDX, petrographic, and XRD analyses of heated samples at 600 and $800{ }^{\circ} \mathrm{C}$ were compared with the analyses at $22^{\circ} \mathrm{C}$.

\subsection{SEM-EDX Analysis}

The SEM-EDX (elemental) analysis results of the representative samples of microschist at 22,600 , and $800{ }^{\circ} \mathrm{C}$ obtained from five iterated values under normalized conditions are presented in Figure 7. The findings show that the samples predominantly consist of oxygen 
$(\mathrm{O})$ and silicon $(\mathrm{Si})$, suggesting quartz as the major mineral in the studied rock. The same minor elements can be found in all three samples (Figure 7a-c), except for sulfur (S), which cannot be seen in S1 (Figure 7a), which may be due to the heterogeneous nature of the studied rock sample. It cannot be confirmed whether the effect of heat causes the observed difference in percentage elemental composition in the samples. The weight (\%) and atomic percentage of elements present in the studied samples are presented in Figure $7 \mathrm{~d}$ and Table 1, respectively.

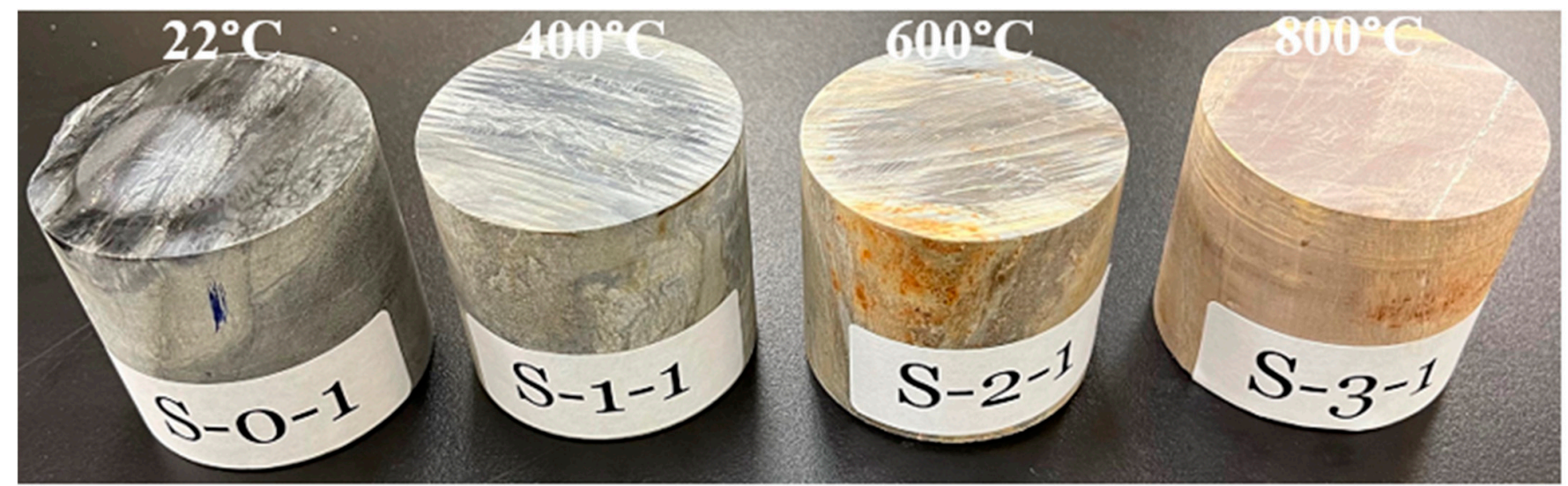

Figure 6. Effect of high temperature on microschist's surface color (a sample is sellected from each studied set).
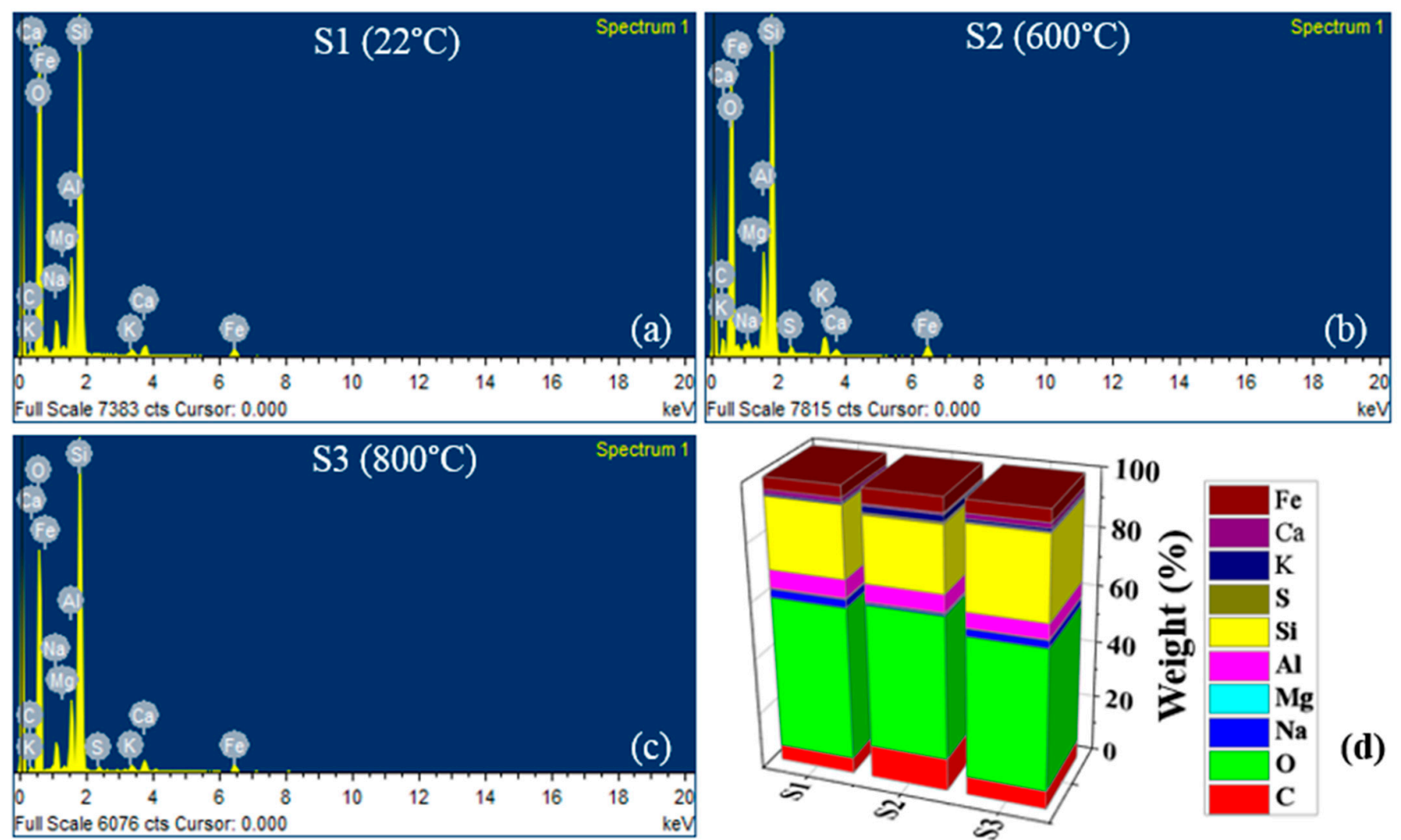

Figure 7. EDX results of representative samples (a) S1 $\left(22^{\circ} \mathrm{C}\right),(\mathbf{b}) \mathrm{S} 2\left(400{ }^{\circ} \mathrm{C}\right),(\mathbf{c}) \mathrm{S} 3\left(800^{\circ} \mathrm{C}\right)$, (d) weight $(\%)$ of elements in the samples S1, S2, and S3. 
Table 1. Elements (atomic \%) present in the samples S1 $\left(22^{\circ} \mathrm{C}\right), \mathrm{S} 2\left(600^{\circ} \mathrm{C}\right)$, and $\mathrm{S} 3\left(800^{\circ} \mathrm{C}\right)$.

\begin{tabular}{ccccccccccc}
\hline \multirow{2}{*}{ Sample } & \multicolumn{10}{c}{ Elements (Atomic \%) } \\
\cline { 2 - 11 } & $\mathbf{C}$ & $\mathbf{O}$ & $\mathbf{N a}$ & $\mathbf{M g}$ & $\mathbf{A l}$ & $\mathbf{S i}$ & $\mathbf{S}$ & $\mathbf{K}$ & $\mathbf{C a}$ & $\mathbf{F e}$ \\
\hline $\mathrm{S} 1\left(22^{\circ} \mathrm{C}\right)$ & 8.58 & 64.88 & 2.40 & 0.34 & 4.43 & 16.91 & - & 0.37 & 0.69 & 1.39 \\
\hline $\mathrm{S} 2\left(600^{\circ} \mathrm{C}\right)$ & 17.67 & 58.69 & 0.61 & 0.27 & 4.15 & 15.11 & 0.43 & 1.05 & 0.32 & 1.71 \\
\hline $\mathrm{S} 3\left(800^{\circ} \mathrm{C}\right)$ & 10.31 & 60.43 & 2.23 & 0.21 & 3.78 & 19.91 & 0.29 & 0.46 & 0.86 & 1.52 \\
\hline
\end{tabular}

\subsection{Petrographic Analysis}

To describe the texture, mineral composition and alteration of the studied samples, petrographic analysis was performed on as-received (unheated) microschist samples and heated samples which reflected color change i.e samples heated to 600 and $800{ }^{\circ} \mathrm{C}$. Figure 8 presents the petrographic analysis results for the as-received representative sample. The findings show that the primary rock texture has been completely over-printed by metamorphic recrystallization and deformation. The rock is highly fine-grained, recrystallized, foliated, and shows laminated fabric (Figure 8a). Foliation is marked by alignment and orientation of microcrystalline flaky phyllosilicate (chlorite) parallel to the deformation plane (Figure $8 \mathrm{~d}, \mathrm{f})$. The rock is traversed by late fractures that are dominantly healed by quartz $(\mathrm{Q})$ and later by carbonate (Figure $8 \mathrm{f}$ ). This observation shows that metamorphic recrystallization and propylitic alteration made it difficult to establish the primary rock composition. The findings indicate that the rock consists of recrystallized quartz (with traces of feldspar), phyllosilicates (chlorite and likely muscovite), epidote, opaque (likely pyrite), and rare unidentified carbonate (Figure $8 \mathrm{c}-\mathrm{f}$ ). The recrystallized quartz is microcrystalline and xenomorphic in nature, with different grain sizes that show alignment parallel to the foliation plane. The chlorite has extremely fine grains, and their alignment and orientation mark the foliation plane (Figure $8 \mathrm{c}-\mathrm{f}$ ). Two varieties of epidote are noted: (1) the more common variety is extremely fine-grained, xenomorphic, and occurs in microcrystalline, anhedral granular aggregates. Such microscopic, tiny individual aggregates occur in scattered-to-dense dissemination and display vague orientation (Figure 8c,e). Due to the extremely fine-grained nature of this epidote, its identity is not positively confirmed. (2) The less common type is relatively fine-grained and is of the zoisite variety. The observed opaque grains show the effect of metamorphic deformation, where opaque grains are stretched, elongated, and oriented parallel to the deformation plane (Figure 8c,e).

The results of petrographic analysis of the sample heated to $600{ }^{\circ} \mathrm{C}$ are micrographically presented in Figure 9. The findings indicate that the rock sample displays very fine-grained laminated texture where segregated bands of quartz-chlorite-rich layers are separated by quartz-rutile-rich layers (Figure 9). Microfractures were noticed with fillings of quartz that displays displacement (micro-fault) along the foliation plane (Figure 8a). This displacement may occur due to heating. As earlier noted for the unheated sample, intense metamorphic recrystallization and deformation has obscured the determination of primary rock composition. The recrystallized rock consists predominantly of quartz, chlorite, opaque grains, and a pale brownish phase resembling rutile or biotite (Figure $9 \mathrm{~b}, \mathrm{~d}, \mathrm{f}$ ). Quartz (with feldspar) is extremely fine-grained and displays preferred orientation parallel to foliation plane (Figure 9). Chlorites and rutile/biotite have very fine grains with an almost similar grain morphology. The tiny grains of rutile/biotite are aligned and oriented parallel to the foliation plane, similarly to chlorite. The epidote has extremely fine grains, is xenomorphic in habit, and occurs in anhedral scattered granular aggregates. Opaque grains are also observed that show the effect of metamorphic deformation, where opaque grains are commonly aligned parallel to the deformation plane with less elongation compared to the unheated sample. There is a possibility that the expansion of grains occurs due to heating, which may had led to microfracturing and grain deformation (Figure 9). 


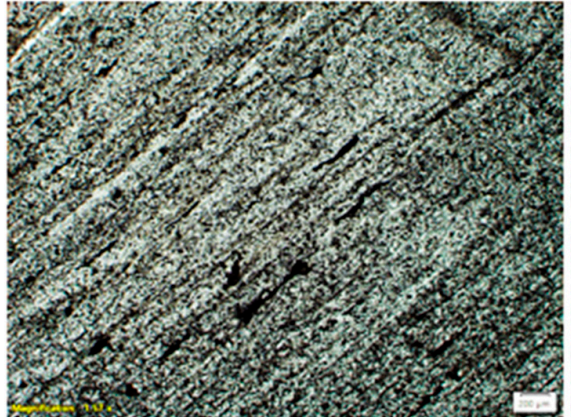

(a)

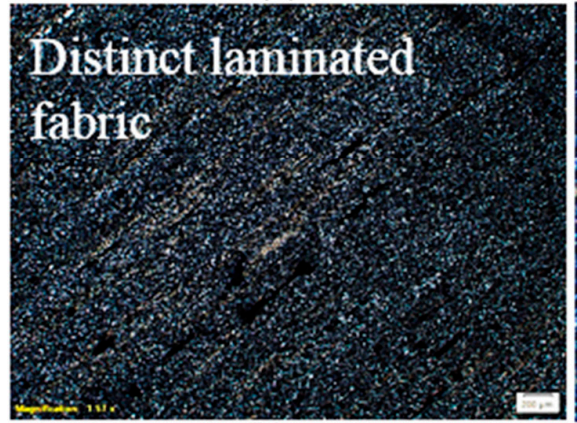

(b)

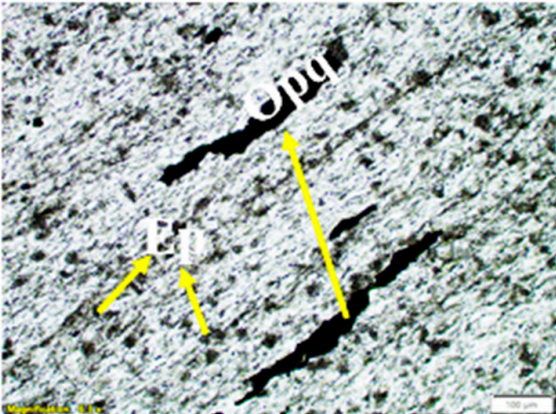

(c)

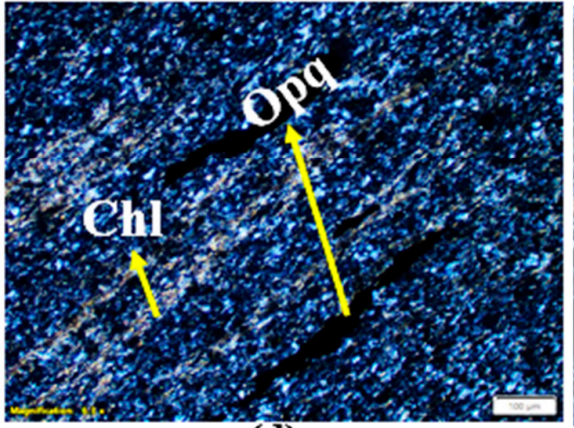

(d)

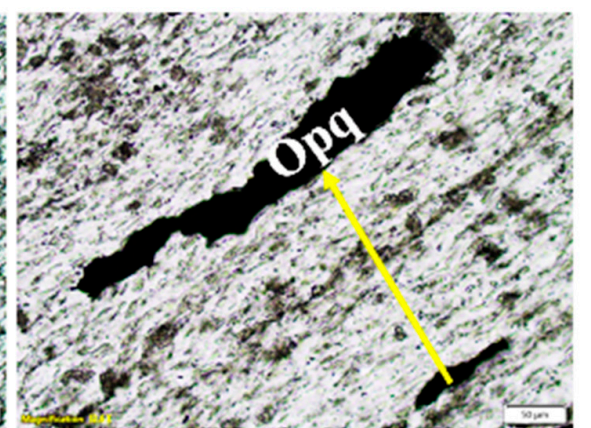

(e)

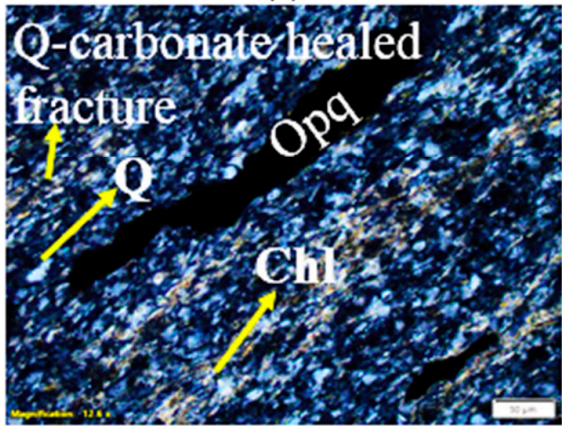

(f)

Figure 8. Results of petrographic analysis for microschist sample at room temperature $\left(\mathrm{S} 1 ; 22{ }^{\circ} \mathrm{C}\right)$; images (a-f) were taken at different magnifications (a,b: $1.57 \times ; \mathbf{c}, \mathbf{d}: 6.3 \times ; \mathbf{e}, \mathbf{f}: 12.6 \times)$ to reveal rock texture, mineral composition, and alteration in microschist (metasiltstone). Image (a) (PPL: plane polarized light) and image (b) (CPL: cross-polarized light) display fine-grained laminated texture in metasiltstone (microschist). Image (c) (PPL) and (e) (PPL) show the opaque scattered epidote. Image (d) (PPL) and (f) (CPL) display chlorite-rich bands intercalated within quartz-rich bands. Opaque (Opq) grains (dark) that are aligned, stretched, and elongated parallel to foliation plane were noted. The rock is extremely finegrained, laminated and consists predominantly of (1) quartz (Q) (gray in CPL), where quartz grains are commonly aligned parallel to foliation plane, (2) chlorite (Chl; pale green), which is platy-to-flaky in nature, and the alignment of which marks the foliation plane, (3) epidote (Ep), which occurs in microcrystalline, anhedral granular aggregates in scattered-to-dense disseminations, which locally show subalignment in the plane of deformation, and (4) opaque grains (Opq; dark).

For the sample heated up to $800{ }^{\circ} \mathrm{C}$, the petrographic analysis results are shown in Figure 10. Similar to the samples at 22 and $600^{\circ} \mathrm{C}$, the primary rock texture is completely overprinted by metamorphic recrystallization and deformation. The rock is extremely finegrained and displays laminated and micro-foliated fabric. The orientation of microscopic platy chlorite and rutile or biotite flakes defines the foliation planes. Microcrystalline quartz (+feldspar) grains and opaque grains also display a preferred alignment parallel to the foliation plane. Quartz-chlorite, epidote and some opaque grains form slightly dark-grayish segregated bands that are separated by thin, pale reddish-brown bands that are also composed of quartz, chlorite, epidote, with the reddish-brown mineral being suggested to be rutile or biotite, and some oxidized opaque grains, which give the reddish coloration to the bands where they are common. The rock sample also shows mild propylitic alteration, marked by the common presence of chlorite and epidote. The deformation of grains in this sample (Figure 10c,e) is higher than that observed for the sample heated to $600{ }^{\circ} \mathrm{C}$ (Figure 9c,e). This may be associated with the effect of higher temperature on the microscopic structure of the sample.

\subsection{SEM Analysis}

For further investigation of the effect of temperature on the microstructural properties of the microschist, SEM analyses of the unheated $\left(22^{\circ} \mathrm{C}\right)$ and heated $\left(800^{\circ} \mathrm{C}\right)$ samples were compared, as presented in Figure 11. It can be seen that the rock samples show microscopic xenomorphic structures with different sizes of grains, as earlier observed using petrographic thin section analysis. Comparing images (a) and (b) (Figure 11), it 
can be observed that grains in the image (b) show a more deformed microstructure (as indicated on the image (b)). This may be attributed to the effect of high temperature on the microcrystalline structure of the studied rock sample. Images taken at higher magnification show that apart from structural deformation, the splitting of grains and microcracks can be observed after heating (comparing image (c) and image (d); Figure 11).

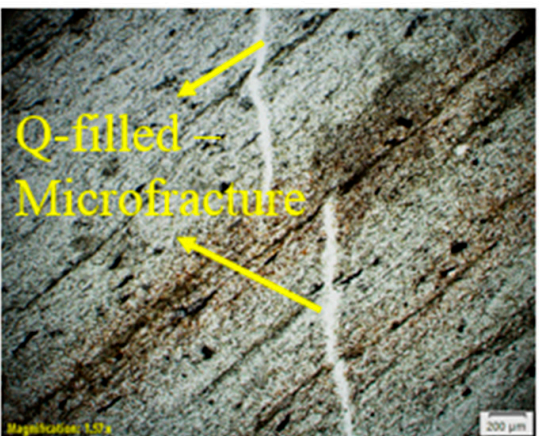

(a)

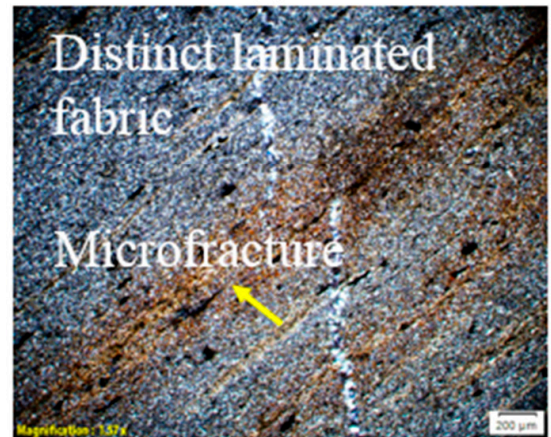

(b)

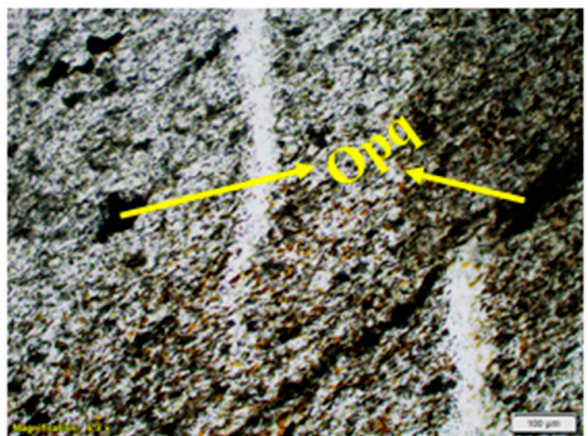

(c)

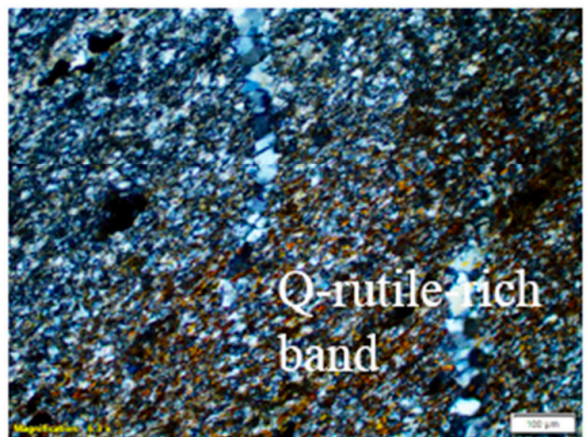

(d)

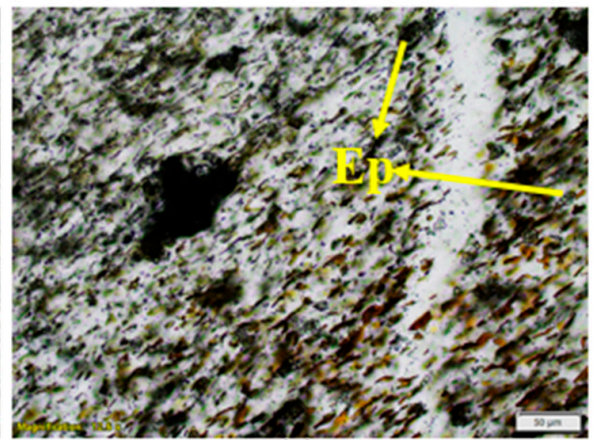

(e)

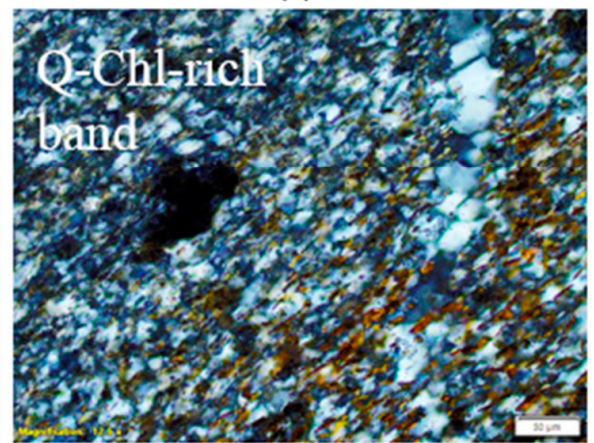

(f)

Figure 9. Results of petrographic analysis for microschist sample at $600{ }^{\circ} \mathrm{C}(\mathrm{S} 2)$; images (a-f) were taken at different magnifications (a,b: $1.57 \times$; c,d: $6.3 \times$; e,f: $12.6 \times)$. Images $(\mathbf{a}, \mathbf{c}, \mathbf{e})$ were taken using PPL, while images $(\mathbf{b}, \mathbf{d}, \mathbf{f})$ were taken using CPL. Image (b) displays very fine-grained laminated texture with segregated light (quartz-chlorite-rich band) and dark (quartz-rutile/biotite-rich band) layering. Tiny, elongated opaque grains (dark) aligned parallel to the foliation plane. Image (c) (PPL) and (d) (CPL) show that rock predominantly consists of quartz (gray in CPL), together with chlorite, rutile or biotite, minor epidote, and opaque grains (dark). Chlorite (pale greenish) occurs in an extremely fine-grained (microscopic) form, is platy-to-flaky in nature, and chlorite grains show alignment parallel to the foliation plane. Rutile or biotite (Brownish in color) displays a similar mode of occurrence, grain size, and morphology as displayed by chlorite. The epidote is minor, occurs in microcrystalline granular aggregates forming scattered-to-dense disseminations, and locally shows alignment parallel to the foliation plane. Q: quartz; Chl: chlorite; Opq: opaque; Ep: epidote.

\subsection{XRD Analysis}

Having identified elements in the studied samples and confirmed some minerals therein using SEM-EDX and petrographic (thin section) analysis, respectively, there is a need to characterize the samples further to identify other suspected minerals as suggested using the thin section method. XRD is a suitable method in this regard. The unheated $\left(22{ }^{\circ} \mathrm{C}\right)$ and heated samples $\left(600\right.$ and $\left.800{ }^{\circ} \mathrm{C}\right)$ were characterized to identify the mineral phases and their changes due to high temperatures. The obtained XRD peaks were matched with built-in standard mineral phases XRD-patterns in "PowderX" and "Match!" softwares, and also compared with published work [41,48,50,51]. The findings show that the studied microschist consists of quartz, albite, clinochlore, biotite, muscovite, epidote, pyrite, zoisite, rutile, and magnesite (Figure 12 and Table 2). The unknown types of feldspar, carbonate, and opaque grain suggested using petrographic analysis are confirmed to be albite, magnesite, and pyrite, respectively. The XRD analysis also confirmed that the chlorite observed in photomicrographs of thin sections is chlinochlore, and another phyllosilicate mineral, muscovite, is present in the studied microschist, as indexed in XRD peaks (Figure 12). 
Furthermore, reddish-brown, very-fine grains, suggested to be rutile or biotite using petrographic analysis, were confirmed to be both rutile and biotite, using the XRD method. Overall, the XRD results agree with those obtained using both SEM-EDX and petrographic analyses. Due to heating, the intensities of quartz increased, while that of albite decreased and nearly disappeared at $800{ }^{\circ} \mathrm{C}$ (Figure 12). This can be attributed to the change in quartz (the primary mineral in the studied microschist rock) from the $\alpha$ to $\beta$ phase at around $573{ }^{\circ} \mathrm{C}$ and mineral decomposition after $600{ }^{\circ} \mathrm{C}$ [45].

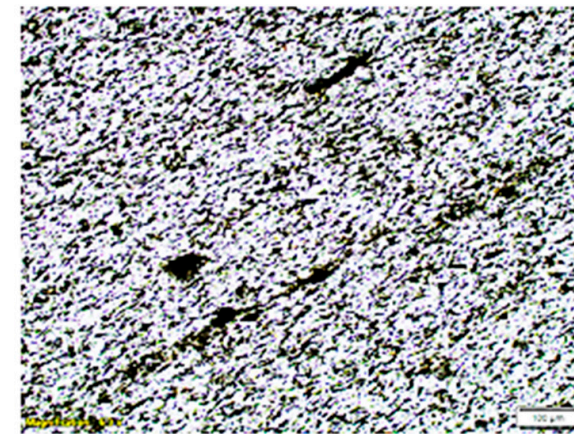

(a)

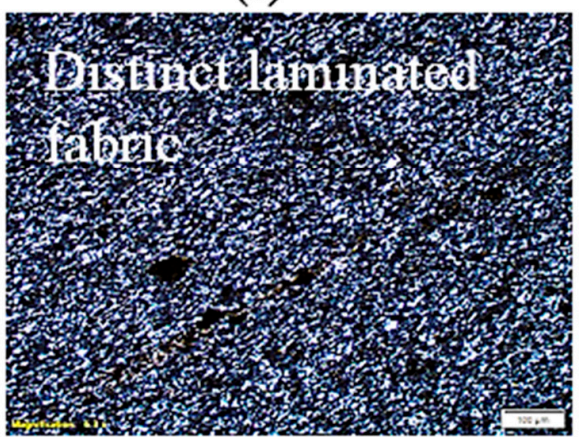

(b)

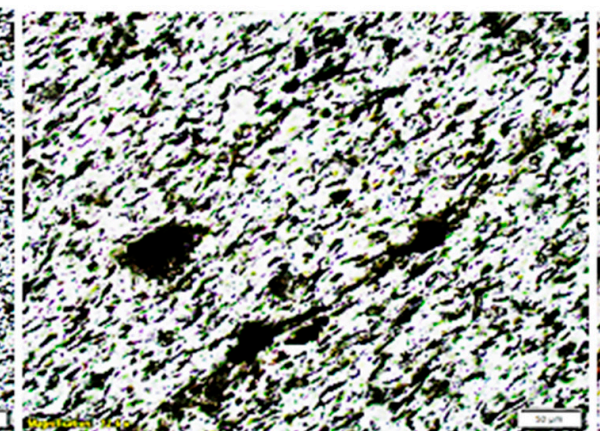

(c)

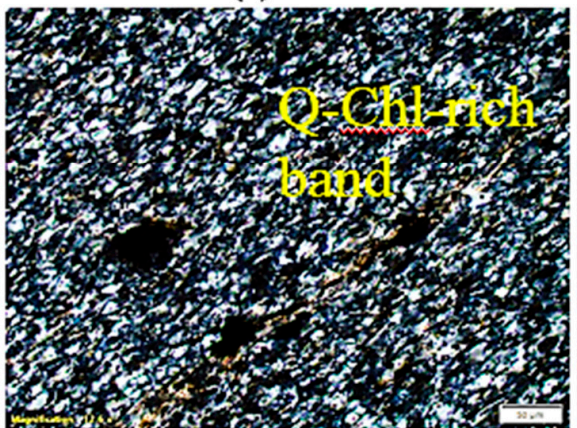

(d)

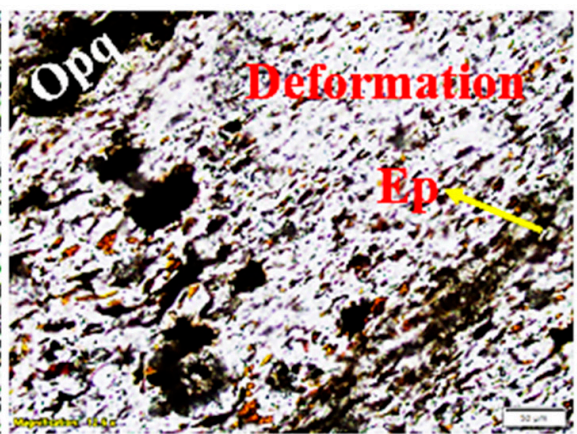

(e)

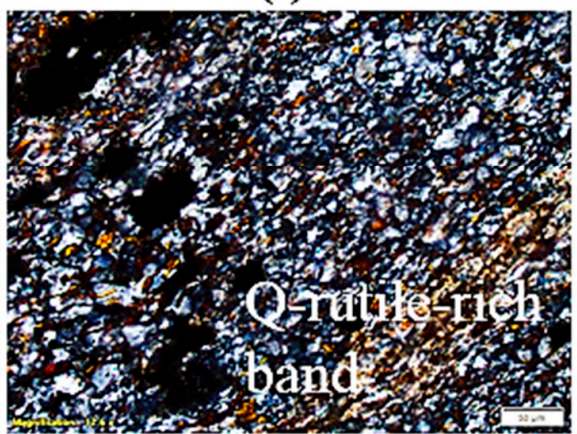

(f)

Figure 10. Results of petrographic analysis for microschist sample at $800{ }^{\circ} \mathrm{C}(\mathrm{S} 3)$, images $(\mathbf{a}, \mathbf{b})$ display fine-grain laminated texture of microschist, and images (c,e) (PPL) show epidote (EP), opaque grains (Opq), and grain deformation. It is predominantly composed of microcrystalline quartz (Q), together with pale-green chlorite (Chl), epidote (Ep), and a platy, dark opaque-like mineral (rutile or biotite) plus opaque grains (iron sulfide). Images (e,f), having an analogous texture with images $(\mathbf{a}-\mathbf{d})$, were taken from the slightly reddish zone of the thin section. Images $(\mathbf{d}, \mathbf{f})$ display the presence of a few brownish to reddish platy grains (rutile or biotite) that locally give the reddish-brown coloration to the rock assemblage.

Table 2. Mineral phases, crystallite sizes, weight percentage, and registration numbers of minerals in the studied microschist at room temperature.

\begin{tabular}{ccccc}
\hline Mineral Phase & Chemical Formula & Crystallite Size (̊) & Weight (\%) & Registration Number \\
\hline Quartz $($ low $)$ & $\mathrm{SiO}_{2}$ & 413.8 & 57.3 & $96-101-1160$ \\
\hline Muscovite & $\mathrm{H}_{4} \mathrm{~K}_{2}(\mathrm{Al}, \mathrm{Fe})_{6} \mathrm{Si}_{6} \mathrm{O}_{24}$ & 382.9 & 11.4 & $96-901-6413$ \\
\hline Rutile & $\mathrm{TiO}_{2}$ & 527.4 & 7.5 & $96-900-4145$ \\
\hline Albite & $\mathrm{Na}\left(\mathrm{AlSi}_{3} \mathrm{O}_{8}\right)$ & 670.7 & 6.9 & $96-900-0587$ \\
\hline Clinochlore & $\mathrm{Mg}_{5} \mathrm{Al}\left(\mathrm{Si}_{3} \mathrm{Al}\right) \mathrm{O}_{10}(\mathrm{OH})_{8}$ & 332.6 & 5.9 & $96-900-8043$ \\
\hline Zoisite & $\mathrm{Ca}_{2} \mathrm{Al}_{3}\left(\mathrm{SiO}_{4}\right)\left(\mathrm{Si}_{2} \mathrm{O}_{7}\right) \mathrm{O}(\mathrm{OH})$ & 336.7 & 4.8 & $96-901-4730$ \\
\hline Biotite & ${\mathrm{Al} \mathrm{Fe} \mathrm{Mg}_{2} \mathrm{O}_{12} \mathrm{Si}}_{3}$ & 320.3 & 3.6 & $96-900-1267$ \\
\hline Epidote & $\mathrm{Ca}_{2}\left(\mathrm{Al}_{2} \mathrm{Fe}\right)\left(\mathrm{SiO}_{4}\right)\left(\mathrm{Si}_{2} \mathrm{O}_{7}\right) \mathrm{O}(\mathrm{OH})$ & 311.2 & 1.0 & $96-900-0039$ \\
\hline Magnesite & $\mathrm{MgCO}_{3}$ & 316.2 & 0.9 & $96-900-2816$ \\
\hline Pyrite & $\mathrm{FeS}_{2}$ & 402.4 & 0.7 & $96-901-5843$ \\
\hline
\end{tabular}


(a)

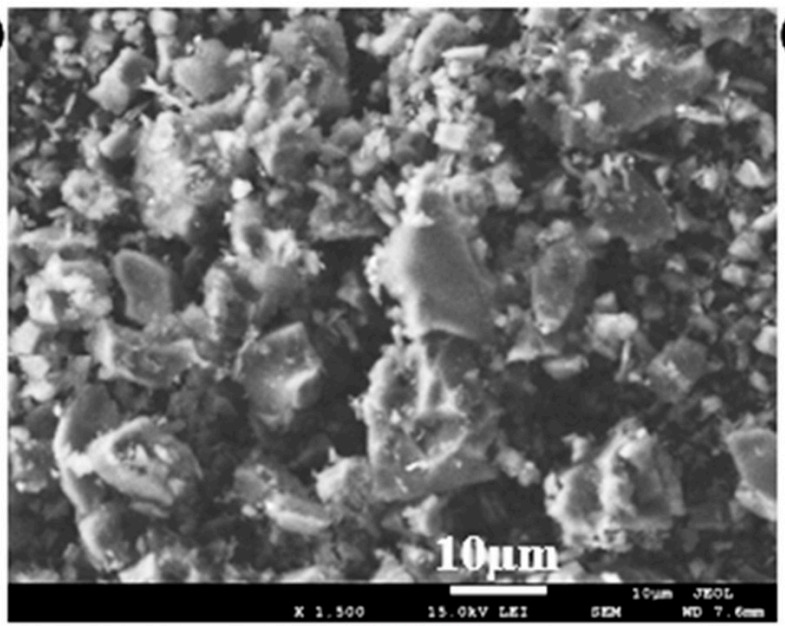

(b)

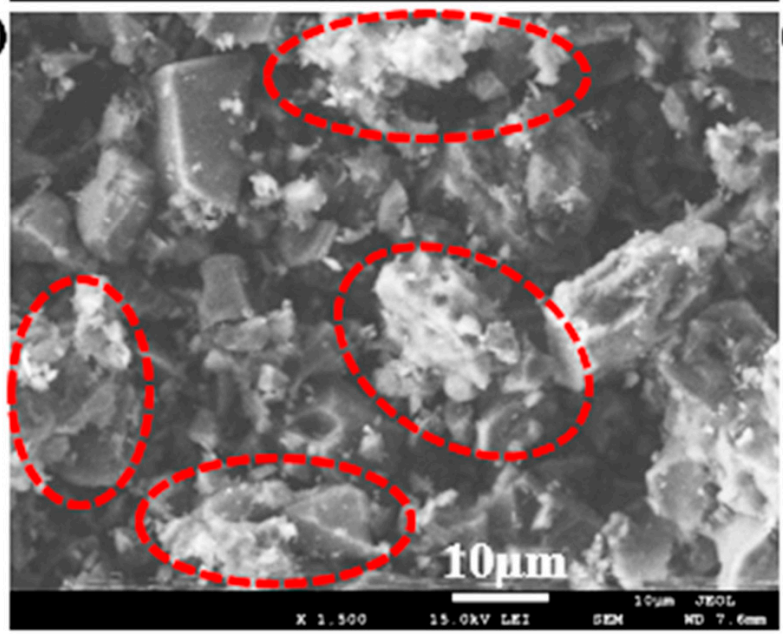

(c)

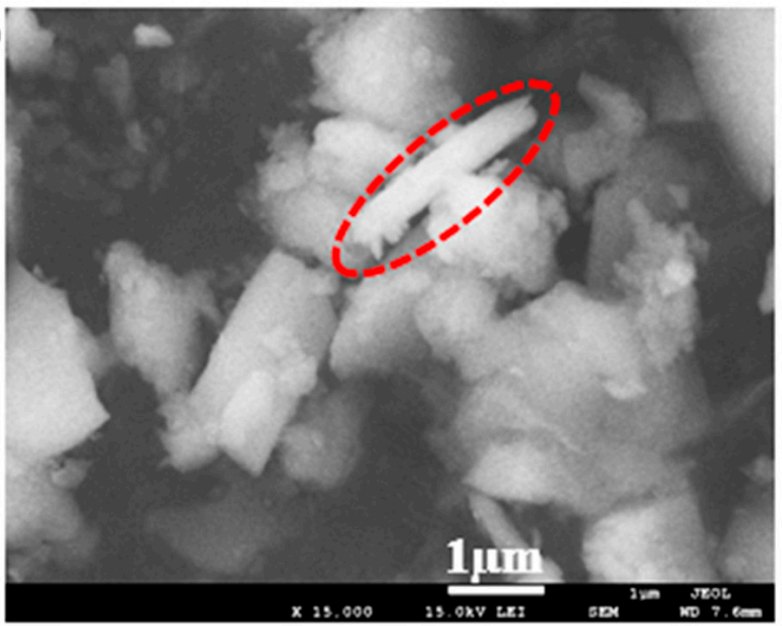

(d)

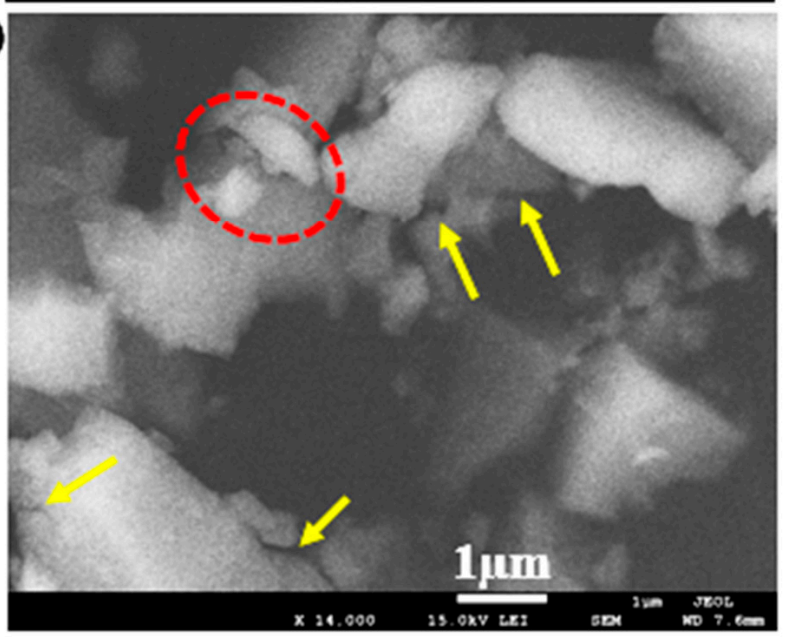

Figure 11. SEM micrographs of the microschist samples: (a) sample at $22{ }^{\circ} \mathrm{C}(1500 \times)$, (b) sample at $800{ }^{\circ} \mathrm{C}(1500 \times)$, (c) sample at $22{ }^{\circ} \mathrm{C}(14,000 \times)$, (d) sample at $800{ }^{\circ} \mathrm{C}(14,000 \times)$.

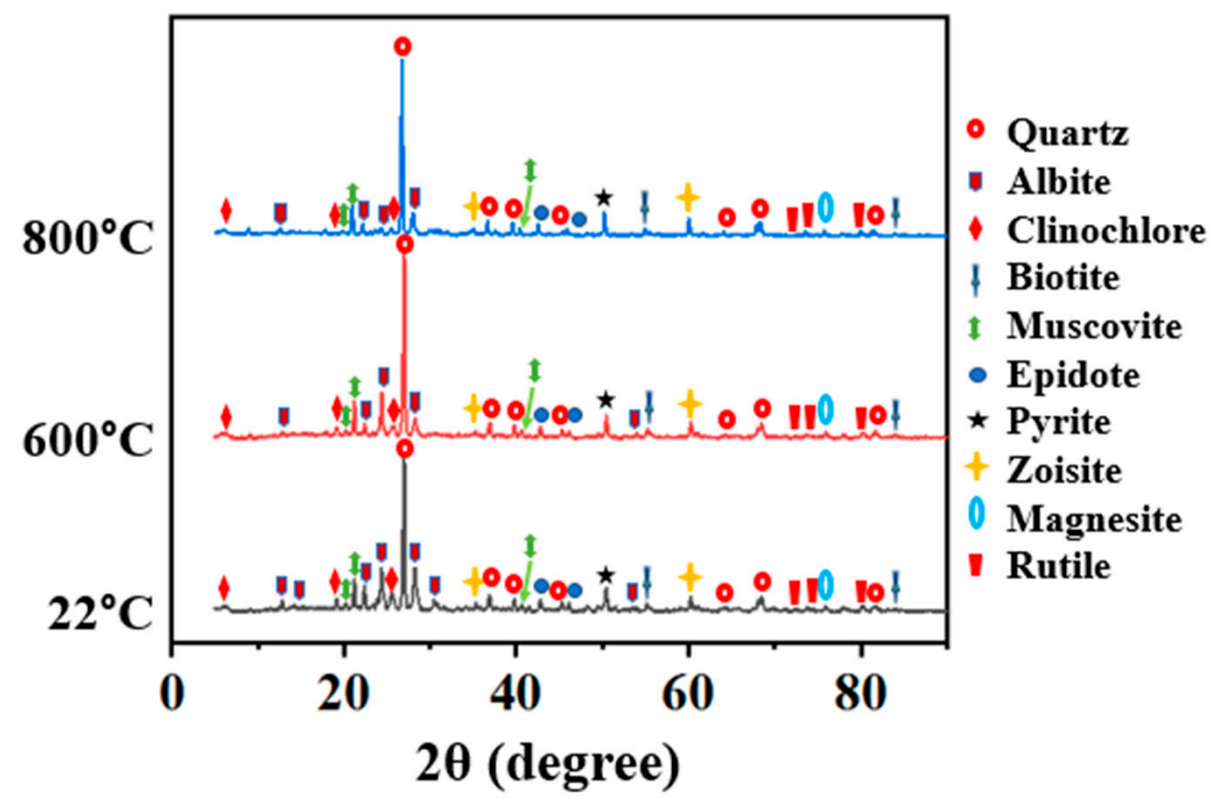

Figure 12. Results of $X R D$ analysis of the studied microschist samples at 22,600 , and $800{ }^{\circ} \mathrm{C}$. 


\subsection{Dry Density}

Figure 13 presents the results of dry densities of the studied microschist at different testing temperatures using a set of samples for each temperature. Whether considering the whole samples together (i.e., set 1 to set 4 ) or individually, set-by-set (i.e., set 1 , set 2 , set 3 and set 4$)$ tested at room temperature $\left(2{ }^{\circ} \mathrm{C}\right)$, results show that the average dry density of the studied microschist is approximately the same, i.e., $2.723 \mathrm{~g} / \mathrm{cm}^{3}$. This reflects a successful strategy of sample selection to be used for the different intended tests. The same is confirmed again where few outliers (only three) can be noticed for the whole forty samples tested at room temperature (Figure 13). Fortunately, only one outlier is within the samples subjected to heating (one of the ten samples named set 4 that are heated to $800{ }^{\circ} \mathrm{C}$ ). Figure 13 also confirms that dry densities of the studied microschist samples fall within 1.5-times the interquartile range (IQR); which indicates low variability. Both statistics emphasize that the technique of sample categorization used in this study mitigated the effect of anisotropic property of the microschist [40]. Considering set 2, set 3 , and set 4 which were tested at room temperature and at high temperatures (Figure 13), it can be observed that no noticeable change in dry density occurs for set 2 , meanwhile, dry density changes can be noticed for set 3 and set 4 (Figure 13). At $800{ }^{\circ} \mathrm{C}$ (set 4), the dry density of the studied microschist decreased by about $0.97 \%$. This decrease in density after heating can be explained in the light of already-published data, where slight mass loss and a small increase in volume due to change in quartz from $\alpha$ to $\beta$ at a temperature around $573{ }^{\circ} \mathrm{C}$ and thermal mineral decomposition above $600{ }^{\circ} \mathrm{C}$ [45]. A similar decrease in density has been reported for granodiorite [45] and granite [44] at the same heating rate, as employed in this study $\left(5^{\circ} \mathrm{C} / \mathrm{min}\right)$. The results show that density of granodiorite $\left(600^{\circ} \mathrm{C}\right)$ and granite $\left(800{ }^{\circ} \mathrm{C}\right)$ decreased by 2.46 and $2.80 \%$, respectively $[44,45]$.

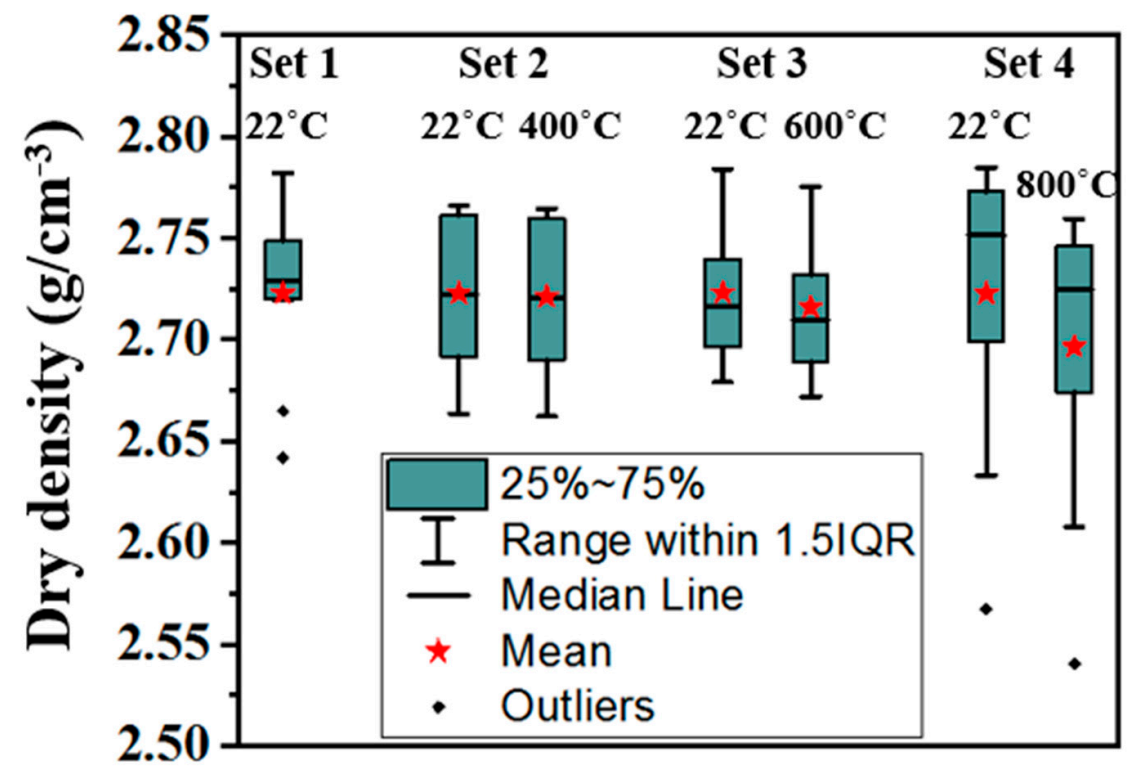

Figure 13. Results of the statistical analysis of dry density of the studied microschist samples (Set 1: S-0-1 to S-0-10, Set 2: S-1-1 to S-1-10, Set 3: S-2-1 to S-2-10, and Set 4: S-3-1 to S-3-10).

\subsection{P-Wave Velocity}

Figure 14 shows four different sets of P-wave velocity testings. In each testing, ten samples were used at different temperatures, as earlier described. Figure 14 also presents the P-wave velocities within 1.5IQR, median, mean, and outliers (P-wave velocities below or above 1.5IQR) as a statistical comparison among the different studied samples. The mean P-wave velocity of the forty representative as-received (unheated) studied rock samples $\left(22{ }^{\circ} \mathrm{C}\right)$ is $5814.5 \mathrm{~m} / \mathrm{s}$, with a standard deviation of $35.9 \mathrm{~m} / \mathrm{s}$. It can be observed that at room temperature, only two outliers are noted out of forty tested samples (Figure 14). The 
few noticed outliers explicitly reflect that sample selection and categorization mitigated the effect of nonhomogeneous and anisotropic nature of the studied rock. On the other hand, among the thirty heated samples, only one outlier is observed which is the P-wave velocity result for one of the ten samples heated to $400{ }^{\circ} \mathrm{C}$. The few samples with outliers in their $\mathrm{P}$-wave velocities for either heated or unheated samples reflect a reproduceable results. It can be seen that as with dry density, the average (mean) P-wave velocity of the studied samples decreases as the temperature increases, indicating changes in the rock's internal structure which may be microcracks due to thermal expansion of grains [47,52]. At 400, 600 , and $800{ }^{\circ} \mathrm{C}$, the mean P-wave velocity decreased by $4.14,7.07$, and $34.23 \%$, respectively. The rate decreases in density and rate decreases in P-wave velocity have a similar trend. The correlation between the two parameters is established, as presented in Figure 15. It can be seen that the correlation between the two parameters is linear, with a coefficient of determination (COD; $\mathrm{r}^{2}$ ) 0.9897. Interestingly, Sun et al. (2017) obtained almost the same $\mathrm{r}^{2}$ value of 0.989 between the mass-loss rate and the rate decrease in P-wave velocity of sandstone after their heating experiment [53]. It can be inferred that as the temperature increases, the mass slightly decreases, and the volume of rock increases (starting from around $600{ }^{\circ} \mathrm{C}$; after $\alpha-\beta$ quartz-inversion), leading to a decrease in the rock's density and P-wave velocity [53].

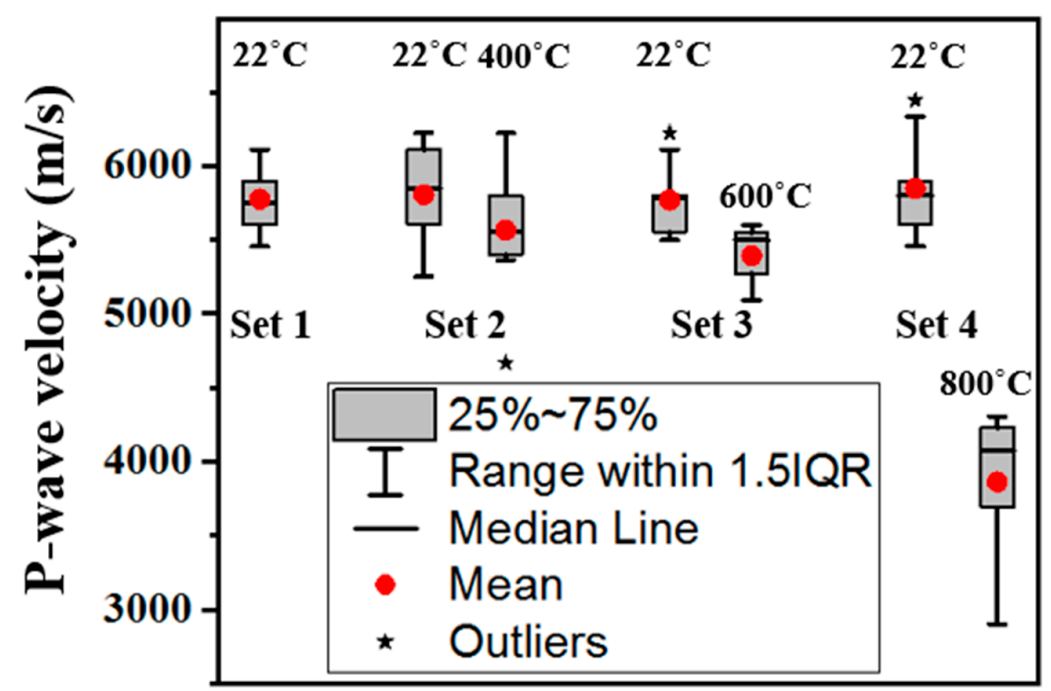

Figure 14. Results of the statistical analysis of P-wave velocities of the studied microschist samples.

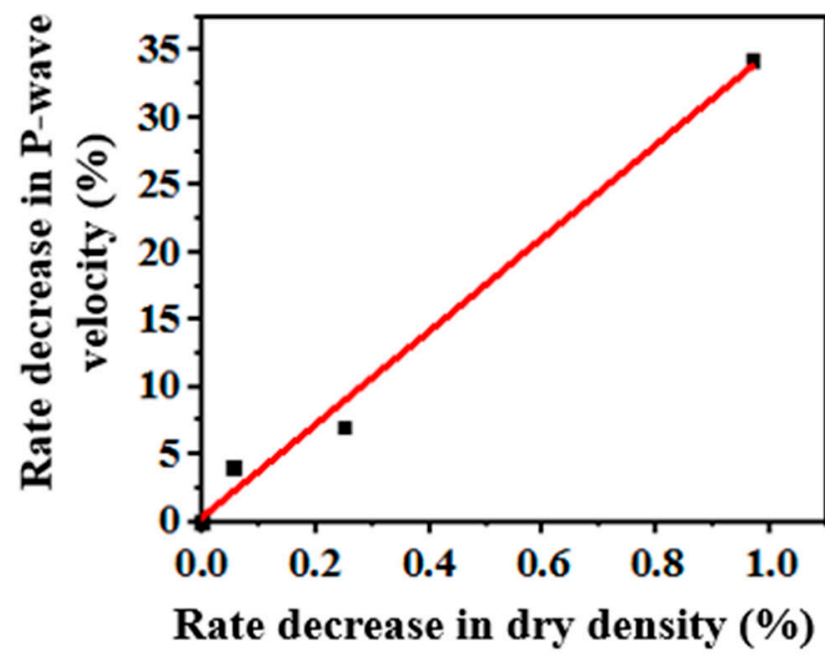

\begin{tabular}{|l|c|}
\hline Equation & $\mathrm{y}=\mathrm{a}+\mathrm{b}^{\star} \mathrm{x}$ \\
\hline Plot & $\mathrm{B}$ \\
\hline Weight & No Weighting \\
\hline Intercept & $0.33591 \pm 1.2504$ \\
\hline Slope & $34.63634 \pm 2.499$ \\
\hline Residual Sum of Squar & 7.44705 \\
\hline Pearson's r & 0.99483 \\
\hline R-Square (COD) & 0.98969 \\
\hline Adj. R-Square & 0.98454 \\
\hline
\end{tabular}

Figure 15. Correlation between rate decrease in dry density and rate decrease in P-wave velocity of the studied microschist at high temperature. 


\subsection{UCS}

Figure 16a shows the microcracks generated due to heating at $800{ }^{\circ} \mathrm{C}$, while Figure $16 \mathrm{~b}$ presents the mean UCS (with a 95\% convidence interval (CI)) of the studied samples at $800{ }^{\circ} \mathrm{C}$. It can be observed that the mean UCS of the studied samples decreases almost linearly as the temperature increases (Figure 16b), indicating that increasing temperature leads to the weakening (reduction in strength) of the studied rock sample. A similar, nearly linear decreasing trend of UCS after a heating experiment within the studied temperatures was reported for granite [23]. At 400,600 , and $800{ }^{\circ} \mathrm{C}$, the UCS of the studied microschist decreased by $34.4,56.9$, and $80.1 \%$, respectively. A drastic reduction of up to $78.9 \%$ in the UCS of granite has been reported for the sample heated to $800{ }^{\circ} \mathrm{C}$ [23]. The higher reduction in UCS of the studied microschist at $800^{\circ} \mathrm{C}$ can be attributed to the deformation of grains and microfractures observed using petrographic thin section and SEM analyses. In fact, at this temperature, some cracks can be observed on the samples, as presented in Figure 16a. It can be inferred that as the temperature increases, the grain deformation increases with microfracture. This causes the strength reduction of the studied rock sample. This behavior confirmed that the studied rock sample has exceeded its thermal stability due to recrystallization of grains above $400{ }^{\circ} \mathrm{C}$ and $\alpha-\beta$ quartz-inversion at around $573{ }^{\circ} \mathrm{C}[45,54]$. As with sandstone and limestone, the studied rock sample may not be suitable for thermal energy storage, especially above $600{ }^{\circ} \mathrm{C}$ [54].

(a)
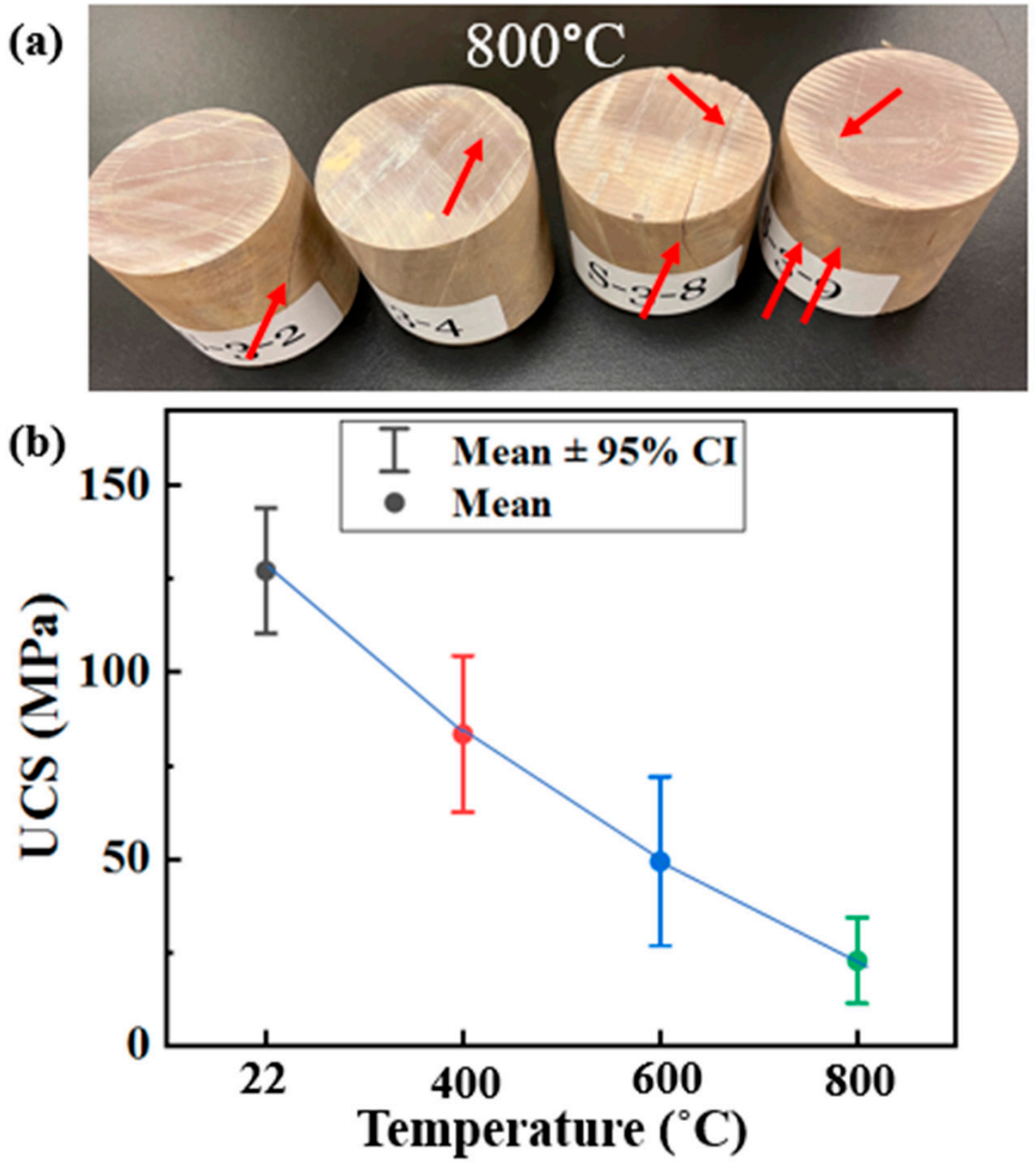

Figure 16. (a) Crack observation for the samples heated at $800{ }^{\circ} \mathrm{C},(\mathbf{b})$ UCS of the studied samples at different temperature. 


\section{Practical Applications}

In engineering applications, material properties are the main parameters for design $[44,55]$. Any change in these properties due to weathering, heating, chemical reactions, etc., will affect the engineering system [55]. The results presented in this paper show that the density, P-wave velocity, and UCS of microschist are temperature-dependent. Therefore, attention should be paid to the exposure of microschist to high temperatures in engineering applications. For example, microschist can be considered as a suitable sub-base aggregate at room temperature. However, if it is heated due to any reason and its density decreases, it may no longer suitable for that application [56]. On the other hand, in underground mining, the decision to support mine opening in microschist environments should take the exposure of the rock mass to heating into consideration. For instance, the microschist used in this study has a UCS value of $127.2 \mathrm{MPa}$ at room temperature, whereas this value reduced to $25.3 \mathrm{MPa}$ at $800{ }^{\circ} \mathrm{C}$, equivalent to an $80.1 \%$ strength reduction; thus, more support will be needed. Additionally, this result suggests that there will be a huge structural failure if a fire occurs in rock engineering structures such as in buildings, tunnels and underground mine channels that contain microshcist rock, especially when temperatures reach above $600{ }^{\circ} \mathrm{C}$. Similarly, the P-wave velocity of the studied microschist changed from $5775.5 \mathrm{~m} / \mathrm{s}$ at room temperature to $5873.2 \mathrm{~m} / \mathrm{s}$ at $800{ }^{\circ} \mathrm{C}$. This can be considered a main guide in designing a blasting pattern in a microschist environment, where the heating of microschist may improve blasting operations [57]. However, this may affect the engineering structure closer to the blasting site.

In underground mines, most reported fire occurrences were caused by diesel-powered equipment and haulage vehicles, mostly with diesel engines [58-60]. Therefore, there is a need for the mining industry to shift to electric vehicles to reduce fire disasters and for a sustainable, cleaner environment. This will not only be of benefit to the mining community (for decent work), but will also reduce global warming (climate action), as part of the Saudi Arabia vision 2030 and the United Nations' (UN) Sustainable Development Goals [61]. Furthermore, incorporating the rock heating test as part of the standard geotechnical campaign in tunnels and underground mine structures will help in mitigating the effect of high temperatures on rock mass [62]. Additionally, economical loss may be avoided in addition to environment protection when risks associated with strength failure of microschist at high temperatures are mitigated through necessary structural underground supports [63]. The results obtained in this study may also be used for modelling the heating behavior of microschists and the consequent effects of high temperature on the microstructural, physical, and mechanical properties of the rock.

\section{Conclusions}

A metamorphic rock type (microschist) from the Najran area of Saudi Arabia has been characterized to investigate the effect of high temperature on its surface appearance, density, P-wave velocity, UCS, and microstructural properties, which may affect the design and stability of underground, deep, geotechnical applications. To achive these, the authors provide a systematic means of sample selection which mitigate the effect of nonhomogeneous properties that are known to microschist and other metamorphic rocks. Different heating experiments were performed from room temperature to 400,600 , and $800{ }^{\circ} \mathrm{C}$, using a total of forty prepared representative intact rock samples at these temperatures. The observations showed that the color of the studied rock changes as the temperature increases, turning from black-gray to red-brown, which was pronounced from $600{ }^{\circ} \mathrm{C}$ and above. A slight change in dry density was observed, with a maximum of a $0.97 \%$ reduction at $800^{\circ} \mathrm{C}$. The P-wave velocity of the studied microschist significantly decreased by up to $34.23 \%$ for samples heated to $800{ }^{\circ} \mathrm{C}$. The studied microschist's strength (UCS) drastically decreased by $34.4,56.9$, and $80.1 \%$ at 400,600 , and $800^{\circ} \mathrm{C}$, respectively. Mineralogical characterization using the XRD method indicated that the peak intensities of quartz increased as the temperature increased and that of albite decreased, indicating a change in the mineral phases and the decomposition of some component minerals at 
high temperatures, leading to the expansion of grains that led to microcracks observed on the studied samples. Petrographic (thin section) and SEM analyses agree with the XRD results, with structural damage observed on the photomicrographs of the studied rock samples. Despite the ultrafine nature of mineral grains in the studied rock, temperature has a significant effect on its physical, mechanical, and microscopic structural properties. The results from this study may be used in the analysis and design process regarding the stability of underground mining, including mitigation of the effects of fires in tunnels and underground mining structures where microschist or other rock types have ultrafine quartz as the dominant mineral.

Author Contributions: Conceptualization, H.M.A., H.A.M.A. and S.O.A.; methodology, H.M.A., H.A.M.A. and S.O.A.; formal analysis, S.O.A.; investigation, H.M.A., H.A.M.A. and S.O.A.; resources, H.M.A., H.A.M.A. and S.O.A.; data curation, S.O.A.; writing-original draft preparation, S.O.A.; writing-review and editing, H.M.A., H.A.M.A. and S.O.A.; visualization, H.M.A. and H.A.M.A.; supervision, H.M.A. and H.A.M.A.; project administration, H.M.A., H.A.M.A. and S.O.A.; funding acquisition, H.M.A., H.A.M.A. and S.O.A. All authors have read and agreed to the published version of the manuscript.

Funding: This project was funded by the Deanship of Scientific Research (DSR) at King Abdulaziz University, Jeddah, under grant no. (G: 570-135-1441). The authors, therefore, acknowledge with thanks the DSR for its technical and financial support.

Institutional Review Board Statement: Not applicable.

Informed Consent Statement: Not applicable.

Data Availability Statement: Not applicable.

Conflicts of Interest: The authors declare no conflict of interest.

\section{References}

1. Zhu, Z.; Kempka, T.; Gamage, P.; Tian, H.; Jiang, G.; Dou, B.; Mei, G. Changes in thermomechanical properties due to air and water cooling of hot dry granite rocks under unconfined compression. Renew. Energy 2021, 170, 562-573. [CrossRef]

2. Liu, X.; Yuan, S.; Sieffert, Y.; Fityus, S.; Buzzi, O. Changes in Mineralogy, Microstructure, Compressive Strength and Intrinsic Permeability of Two Sedimentary Rocks Subjected to High-Temperature Heating. Rock Mech. Rock Eng. 2016, 49, $2985-2998$. [CrossRef]

3. Luo, J.; Wang, L. High-Temperature Mechanical Properties of Mudstone in the Process of Underground Coal Gasification. Rock Mech. Rock Eng. 2011, 44, 749-754. [CrossRef]

4. Gautam, P.K.; Verma, A.K.; Singh, T.N.; Hu, W.; Singh, K.H. Experimental investigations on the thermal properties of Jalore granitic rocks for nuclear waste repository. Thermochim. Acta 2019, 681, 1-13. [CrossRef]

5. Huang, X.; Tang, S.B.; Tang, C.A.; Xie, L.M.; Tao, Z.Y. Numerical simulation of cracking behavior in artificially designed rock models subjected to heating from a central borehole. Int. J. Rock Mech. Min. Sci. 2017, 98, 191-202. [CrossRef]

6. Moník, M.; Nerudová, Z.; Schnabl, P. Investigation of heat-treated artefacts from Pleistocene sites. J. Archaeol. Sci. Rep. 2021, 37, 1-13. [CrossRef]

7. Delagnes, A.; Schmidt, P.; Douze, K.; Wurz, S.; Bellot-Gurlet, L.; Conard, J.N.; Nickel, G.K.; van Niekerk, L.K.; Henshilwood, S.C. Early Evidence for the Extensive Heat Treatment of Silcrete in the Howiesons Poort at Klipdrift Shelter (Layer PBD, 65 ka), South Africa. PLoS ONE 2016, 11, e0163874. [CrossRef]

8. Hu, J.; Sun, Q.; Chen, S.; Zhang, W. The thermodynamic properties variation of cemented clay after treatment at high temperatures. Constr. Build. Mater. 2018, 182, 523-529. [CrossRef]

9. Ozguven, A.; Ozcelik, Y. Investigation of some property changes of natural building stones exposed to fire and high heat. Constr. Build. Mater. 2013, 38, 813-821. [CrossRef]

10. Wasantha, P.L.P.; Guerrieri, M.; Xu, T. Effects of tunnel fires on the mechanical behaviour of rocks in the vicinity-A review. Tunn. Undergr. Space Technol. 2021, 108, 1-17. [CrossRef]

11. Jemmal, Y.; Zari, N.; Asbik, M.; Maaroufi, M. Experimental characterization and thermal performance comparison of six Moroccan rocks used as filler materials in a packed bed storage system. J. Energy Storage 2020, 30, 1-16. [CrossRef]

12. Tiskatine, R.; Oaddi, R.; Ait El Cadi, R.; Bazgaou, A.; Bouirden, L.; Aharoune, A.; Ihlal, A. Suitability and characteristics of rocks for sensible heat storage in CSP plants. Sol. Energy Mater. Sol. Cells 2017, 169, 245-257. [CrossRef]

13. El Alami, K.; Asbik, M.; Agalit, H. Identification of natural rocks as storage materials in thermal energy storage (TES) system of concentrated solar power (CSP) plants-A review. Sol. Energy Mater. Sol. Cells 2020, 217, 1-22. [CrossRef]

14. Nahhas, T.; Py, X.; Sadiki, N. Experimental investigation of basalt rocks as storage material for high- temperature concentrated solar power plants. Renew. Sustain. Energy Rev. 2019, 110, 226-235. [CrossRef] 
15. Gautam, P.K.; Verma, A.K.; Jha, M.K.; Sharma, P.; Singh, T.N. Effect of high temperature on physical and mechanical properties of Jalore granite. J. Appl. Geophys. 2018, 159, 460-474. [CrossRef]

16. Vázquez, P.; Shushakova, V.; Gómez-heras, M. Influence of mineralogy on granite decay induced by temperature increase: Experimental observations and stress simulation. Eng. Geol. 2015, 189, 58-67. [CrossRef]

17. Lianying, Z.; Xianbiao, M.A.O.; Aihong, L.U. Experimental study on the mechanical properties of rocks at high temperature. Sci. China Ser. E Technol. Sci. 2009, 52, 641-646. [CrossRef]

18. Lü, C.; Sun, Q.; Zhang, W.; Geng, J.; Qi, Y.; Lu, L. The effect of high temperature on tensile strength of sandstone. Appl. Therm. Eng. 2017, 111, 573-579. [CrossRef]

19. Liu, S.; Xu, J. An experimental study on the physico-mechanical properties of two post-high-temperature rocks. Eng. Geol. 2015, 185, 63-70. [CrossRef]

20. Mahanta, B.; Vishal, V.; Ranjith, P.G.; Singh, T.N. An insight into pore-network models of high-temperature heat-treated sandstones using computed tomography. J. Nat. Gas Sci. Eng. 2020, 77, 1-21. [CrossRef]

21. Shen, Y.; Zhang, Y.-L.; Gao, F.; Yang, G.-S.; Lai, X.-P. Influence of Temperature on the Microstructure Deterioration of Sandstone Energies 2018, 11, 1753. [CrossRef]

22. Wei, S.; Yang, Y.; Su, C.; Cardosh, S.R.; Wang, H. Experimental Study of the E ff ect of High Temperature on the Mechanical Properties of Coarse Sandstone. Appl. Sci. 2019, 9, 2424. [CrossRef]

23. Chen, Y.; Ni, J.; Shao, W.; Azzam, R. Experimental study on the influence of temperature on the mechanical properties of granite under uni-axial compression and fatigue loading. Int. J. Rock Mech. Min. Sci. 2012, 56, 62-66. [CrossRef]

24. Xiao-li, X.; Zong-xin, K.; Ming, J.; Wen-xuan, G.; Jing, C. Research of microcosmic mechanism of brittle-plastic transition for granite under high temperature. Procedia Earth Planet. Sci. 2009, 1, 432-437. [CrossRef]

25. Yang, J.; Fu, L.; Zhang, W.; Wang, Z. Mechanical property and thermal damage factor of limestone at high temperature. Int. J. Rock Mech. Min. Sci. 2019, 117, 11-19. [CrossRef]

26. Yavuz, H.; Demirdag, S.; Caran, S. Thermal effect on the physical properties of carbonate rocks. Int. J. Rock Mech. Min. Sci. 2010, 47, 94-103. [CrossRef]

27. Brotóns, V.; Tomás, R.; Ivorra, S.; Alarcón, J.C. Temperature influence on the physical and mechanical properties of a porous rock: San Julian's calcarenite. Eng. Geol. 2013, 167, 117-127. [CrossRef]

28. Peng, J.; Rong, G.; Cai, M.; Yao, M.; Zhou, C. Physical and mechanical behaviors of a thermal-damaged coarse marble under uniaxial compression. Eng. Geol. 2016, 200, 88-93. [CrossRef]

29. Saiang, C.; Miskovsky, K. Effect of heat on the mechanical properties of selected rock types-A laboratory study. In Harmonising Rock Engineering and the Environment; Qian, Q., Zhou, Y., Eds.; Taylor \& Francis Group: London, UK, 2012; pp. 815-820. ISBN 978-0-415-80444-8. [CrossRef]

30. Walsh, S.D.C.; Lomov, I.N. Micromechanical modeling of thermal spallation in granite rock. Int. J. Heat Mass Transf. 2013, 65, 366-373. [CrossRef]

31. Hu, J.; Xie, H.; Sun, Q.; Li, C.; Liu, G. Changes in the thermodynamic properties of alkaline granite after cyclic quenching following high temperature action. Int. J. Min. Sci. Technol. 2021, 31, 843-852. [CrossRef]

32. Takarli, M.; Prince, W.; Siddique, R. Damage in granite under heating/cooling cycles and water freeze-thaw condition. Int. J. Rock Mech. Min. Sci. 2008, 45, 1164-1175. [CrossRef]

33. Luc Leroy, M.N.; Marius, F.W.; François, N. Experimental and Theoretical Investigations of Hard Rocks at High Temperature: Applications in Civil Engineering. Adv. Civ. Eng. 2021, 2021, 8893944. [CrossRef]

34. Li, J.; Du, Z.W.; Guo, Z.P. Effect of High Temperature $\left(600^{\circ} \mathrm{C}\right)$ on Mechanical Properties, Mineral Composition, and Microfracture Characteristics of Sandstone. Adv. Mater. Sci. Eng. 2020, 2020, 5072534. [CrossRef]

35. Rathnaweera, T.D.; Ranjith, P.G.; Gu, X.; Perera, M.S.A.; Kumari, W.G.P.; Wanniarachchi, W.A.M.; Haque, A.; Li, J.C. Experimental investigation of thermomechanical behaviour of clay-rich sandstone at extreme temperatures followed by cooling treatments. Int. J. Rock Mech. Min. Sci. 2018, 107, 208-223. [CrossRef]

36. González-Gómez, W.S.; Quintana, P.; May-Pat, A.; Avilés, F.; May-Crespo, J.; Alvarado-Gil, J.J. Thermal effects on the physical properties of limestones from the Yucatan Peninsula. Int. J. Rock Mech. Min. Sci. 2015, 75, 182-189. [CrossRef]

37. Keppert, M.; Fořt, J.; Trník, A.; Koňáková, D.; Vejmelková, E.; Pokorný, J.; Svora, P.; Pavlík, Z.; Černý, R. Behavior of Sandstones Under Heat Treatment. Int. J. Thermophys. 2017, 38, 1-9. [CrossRef]

38. ASTM. D4543 Standard Practices for Preparing Rock Core as Cylindrical Test Specimens and Verifying Conformance to Dimensional and Shape Tolerances; ASTM: West Conshohocken, PA, USA, 2008.

39. ASTM. D5731-08, Standard Test Method for Determination of the Point Load Strength Index of Rock and Application to Rock Strength Classifications; ASTM: West Conshohocken, PA, USA, 2008.

40. Zhang, X.; Ngai, L.W.Y.; Wang, S.; Han, G. Engineering properties of quartz mica schist. Eng. Geol. 2011, 121, 135-149. [CrossRef]

41. Adewuyi, S.O.; Ahmed, H.A.M. Grinding Behaviour of Microwave-Irradiated Mining Waste. Energies 2021, 14, 3991. [CrossRef]

42. Mengting, Z.; Kurniawan, T.A.; Yanping, Y.; Dzarfan Othman, M.H.; Avtar, R.; Fu, D.; Hwang, G.H. Fabrication, characterization, and application of ternary magnetic recyclable $\mathrm{Bi} 2 \mathrm{WO} 6 / \mathrm{BiOI} @ \mathrm{Fe} 3 \mathrm{O} 4$ composite for photodegradation of tetracycline in aqueous solutions. J. Environ. Manage. 2020, 270, 1-11. [CrossRef]

43. Dong, C. PowderX: Windows-95-based program for powder X-ray diffraction data processing. J. Appl. Cryst. 1991, 32, 838. [CrossRef] 
44. Zhu, Z.; Tian, H.; Jiang, G.; Dou, B. Effects of high temperature on rock bulk density. Geomech. Geoengin. 2020, 1-11. [CrossRef]

45. Gomah, M.E.; Li, G.; Bader, S.; Elkarmoty, M.; Ismael, M. Damage evolution of granodiorite after heating and cooling treatments. Minerals 2021, 11, 779. [CrossRef]

46. Li, X.; Huang, S.; Yin, T.; Li, X.; Peng, K.; Fan, X.; Dang, W.; Huang, L. Dynamic properties of thermal shock treated sandstone subjected to coupled dynamic and static loads. Minerals 2021, 11, 889. [CrossRef]

47. Li, Z.; Wong, L.N.Y.; Teh, C.I. Low cost colorimetry for assessment of fire damage in rock. Eng. Geol. 2017, 228, 50-60. [CrossRef]

48. Saeed, A.; Adewuyi, S.O.; Ahmed, H.A.M.; Alharbi, S.R.; AlGarni, S.E. Electric and Dielectric Properties of the Natural Calcite and Quartz. Silicon 2021, 1-12. [CrossRef]

49. Vidana Pathiranagei, S.; Gratchev, I.; Kong, R. Engineering properties of four different rocks after heat treatment. Geomech Geophys. Geo-Energy Geo-Resour. 2021, 7, 1-21. [CrossRef]

50. Fiquet, G.; Guyot, F.; Kunz, M.; Matas, J.; Andrault, D.; Hanfland, M. Structural refinements of magnesite at very high pressureSample: P = 56.6 GPa. Am. Mineral. 2002, 87, 1261-1265. [CrossRef]

51. Choi, H.; Seo, J.Y.; Uhm, Y.R.; Sun, G.M.; Kim, C.S. Crystalline structure and magnetic properties of pyrite FeS2. AIP Adv. 2021, 11, 9-14. [CrossRef]

52. Tang, Z.C.; Sun, M.; Peng, J. Influence of high temperature duration on physical, thermal and mechanical properties of a fine-grained marble. Appl. Therm. Eng. 2019, 156, 34-50. [CrossRef]

53. Sun, H.; Sun, Q.; Deng, W.; Zhang, W.; Lü, C. Temperature effect on microstructure and P-wave propagation in Linyi sandstone. Appl. Therm. Eng. 2017, 115, 913-922. [CrossRef]

54. Becattini, V.; Motmans, T.; Zappone, A.; Madonna, C.; Haselbacher, A.; Steinfeld, A. Experimental investigation of the thermal and mechanical stability of rocks for high-temperature thermal-energy storage. Appl. Energy 2017, 203, 373-389. [CrossRef]

55. Haghighat, A.; Luxbacher, K. Determination of critical parameters in the analysis of road tunnel fires. Int. J. Min. Sci. Technol. 2019, 29, 187-198. [CrossRef]

56. Wang, Y.; Wu, J.; Huang, Z.; Jiang, J.; Yuan, G.; Zhang, Y. Experimental studies on continuous reinforced concrete slabs under single and multi-compartment fires with cooling phase. Fire Saf. J. 2020, 111, 2-25. [CrossRef]

57. Zhang, Z.-X. Effect of Temperature on Rock Fracture. In Rock Fracture and Blasting: Theory and Applications; ButterworthHeinemann: Oxford, UK, 2016; pp. 111-133.

58. Lee, C.; Nguyen, V. A study on the fire propagation characteristics in large-opening multi-level limestone mines in Korea. Geosyst. Eng. 2016, 19, 317-336. [CrossRef]

59. Hansen, R. Fire behavior of mining vehicles in underground hard rock mines. Int. J. Min. Sci. Technol. 2017, 27, 627-634. [CrossRef]

60. Hansen, R.; Ingason, H. Full-Scale Fire Experiments with Mining Vehicles in an Underground Mine; Mälardalen University: Västerås, Sweden, 2013.

61. UNDP; UN-Environment. Managing Mining for Sustainable Development: A Sourcebook; Quan, A., Ed.; United Nations Development Programme: Bangkok, Thailand, 2018; ISBN 978-974-680-421-9.

62. Fei, T.; Antonio, B. Effect of temperature on deep lined circular tunnels in transversely anisotropic elastic rock. Undergr. Space 2016, 1, 79-93. [CrossRef]

63. Sipilä, J.; Auerkari, P.; Heikkilä, A.-M.; Tuominen, R.; Vela, I.; Itkonen, J.; Rinne, M.; Aaltonen, K. Risk and mitigation of self-heating and spontaneous combustion in underground coal storage. J. Loss Prev. Process Ind. 2012, 25, 617-622. [CrossRef] 